\title{
Potential impact of a US climate policy and air quality regulations on future air quality and climate change
}

\author{
Yunha Lee $^{1}$, Drew T. Shindell ${ }^{2}$, Greg Faluvegi ${ }^{3}$, and Rob W. Pinder ${ }^{4}$ \\ ${ }^{1}$ Laboratory for Atmospheric Research, Civil and Environmental Engineering, \\ Washington State University, Pullman, WA, USA \\ ${ }^{2}$ Earth and Ocean Sciences, Nicholas School of the Environment, Duke University, Durham, NC, USA \\ ${ }^{3}$ NASA Goddard Institute for Space Studies and Columbia Earth Institute, New York, NY, USA \\ ${ }^{4}$ NextClimate, Carborro, NC, USA \\ Correspondence to: Yunha Lee (yunha.lee.00@gmail.com)
}

Received: 20 September 2015 - Published in Atmos. Chem. Phys. Discuss.: 9 November 2015

Revised: 9 March 2016 - Accepted: 29 March 2016 - Published: 28 April 2016

\begin{abstract}
We have investigated how future air quality and climate change are influenced by the US air quality regulations that existed or were proposed in 2013 and a hypothetical climate mitigation policy that aims to reduce 2050 $\mathrm{CO}_{2}$ emissions to be $50 \%$ below 2005 emissions. Using the NASA GISS ModelE2 general circulation model, we look at the impacts for year 2030 and 2055. The US energy-sector emissions are from the GLIMPSE project (GEOS-Chem LIDORT Integrated with MARKAL (MARKet ALlocation) for the Purpose of Scenario Exploration), and other US emissions data sets and the rest of the world emissions data sets are based on the RCP4.5 scenario. The US air quality regulations are projected to have a strong beneficial impact on US air quality and public health in year 2030 and 2055 but result in positive radiative forcing. Under this scenario, no more emission constraints are added after 2020, and the impacts on air quality and climate change are similar between year 2030 and 2055. Surface particulate matter with a diameter smaller than $2.5 \mu \mathrm{m}\left(\mathrm{PM}_{2.5}\right)$ is reduced by $\sim 2 \mu \mathrm{g} \mathrm{m}^{-3}$ on average over the USA, and surface ozone by $\sim 8 \mathrm{ppbv}$. The improved air quality prevents about 91400 premature deaths in the USA, mainly due to the $\mathrm{PM}_{2.5}$ reduction $(\sim 74200$ lives saved). The air quality regulations reduce the light-reflecting aerosols (i.e., sulfate and organic matter) more than the lightabsorbing species (i.e., black carbon and ozone), leading to a strong positive radiative forcing (RF) over the USA by both aerosols' direct and indirect forcing: the total RF is $\sim 0.04 \mathrm{~W} \mathrm{~m}^{-2}$ over the globe, and $\sim 0.8 \mathrm{~W} \mathrm{~m}^{-2}$ over the USA. Under the hypothetical climate policy, a future $\mathrm{CO}_{2}$
\end{abstract}

emissions cut is achieved in part by relying less on coal, and thus $\mathrm{SO}_{2}$ emissions are noticeably reduced. This provides air quality co-benefits, but it could lead to potential climate disbenefits over the USA. In 2055, the US mean total $\mathrm{RF}$ is $+0.22 \mathrm{~W} \mathrm{~m}^{-2}$ due to positive aerosol direct and indirect forcing, while the global mean total $\mathrm{RF}$ is $-0.06 \mathrm{~W} \mathrm{~m}^{-2}$ due to the dominant negative $\mathrm{CO}_{2} \mathrm{RF}$ (instantaneous RF). To achieve a regional-scale climate benefit via a climate policy, it is critical (1) to have multinational efforts to reduce greenhouse gas (GHG) emissions and (2) to simultaneously target emission reduction of light-absorbing species (e.g., BC and $\mathrm{O}_{3}$ ) on top of long-lived species. The latter is very desirable as the resulting climate benefit occurs faster and provides cobenefits to air quality and public health.

\section{Introduction}

The US Environmental Protection Agency (EPA)'s air quality regulations have historically been focused on air quality assessment in terms of public health and environmental damages. With the Endangerment Finding under the Clean Air Act in December 2009 (US Environmental Protection Agency, 2009), the EPA sought to understand and provide integrated policy approaches to both mitigate climate change and manage air quality (e.g., US Environmental Protection Agency, 2012). This requires estimating potential climate and air quality impacts of various greenhouse gases (GHGs) 
and short-lived climate pollutants (SLCPs) including some "traditional" pollutants regulated under the Clean Air Act.

With growing interest in identifying potential energy policies that maximize benefits to air quality and reduce climate change impacts, a rapid decision tool for energy and environmental policy has been developed in the US Environmental Protection Agency: GLIMPSE (GEOS-Chem LIDORT Integrated with MARKAL for the Purpose of Scenario Exploration). Under the GLIMPSE project (http://www.epa. gov/AMD/Research/Climate/GLIMPSE.html; Akhtar et al., 2013), the MARKet ALlocation (MARKAL) optimization model (Fishbone and Abilock, 1981; Loughlin et al., 2011) is used to estimate emissions based on energy policy actions, and the adjoint GEOS-Chem global chemical transport model and the LIDORT radiative transfer model (Henze et al., 2012) is used to compute the impact of emissions, chemical fate, and transport on direct radiative forcing. The GLIMPSE decision-making tool examines combined constraints of greenhouse gas emissions, short-lived species direct radiative forcing, and relative cost to examine the tradeoffs between different policy options. Akhtar et al. (2013) present the four emission scenarios based on energy policy and air quality regulations and the impact of these emissions on direct radiative forcing and public health; see the description of emission scenarios in Sect. 2 in this paper.

A major limitation on the climate impact estimates in Akhtar et al. (2013) is that they only use direct radiative forcing of sulfate, black carbon, and organic carbon aerosols; no direct forcing by gas pollutants and no aerosol indirect effects are used. Moreover, their direct radiative forcing estimates cannot account for nonlinear behavior in the impact of emissions on direct radiative forcing (an inherent limitation of an adjoint model). In order to get a more complete assessment of climate impact, we investigate the impact of the GLIMPSE emission scenarios using the NASA Goddard Institute for Space Studies (GISS) ModelE2 general circulation model, i.e., a fully coupled atmospheric chemistry-climate model. We utilize two independent aerosol models coupled to the same GISS ModelE2 climate model to obtain a more robust estimate of aerosol impacts on air quality and climate. Using an entirely different air quality model than Akhtar et al. (2013), our study provides an independent analysis of the air quality component of the impact of the same GLIMPSE emission scenarios.

The paper is organized as follows. Section 2 provides the detailed descriptions of the four emission scenarios developed from GLIMPSE. The NASA GISS ModelE2 description, including a bulk aerosol model and a sectional aerosol microphysics model, is provided in Sect. 3. In Sect. 4, we present the model results and discussions including the changes of gases and aerosols budgets and their radiative forcing under the four scenarios. Conclusions are in Sect. 5.

\section{Scenario descriptions}

To identify the climate and health impacts of US emission reductions, four energy sector scenarios were developed using the MARKet ALlocation (MARKAL) optimization model and are described in detail in Akhtar et al. (2013). Each scenario is specified as a set of emission constraints. MARKAL finds the least-cost set of energy technologies that meet US energy demands while not exceeding the specified emission constraints. Output from MARKAL includes both energy technologies and associated emissions for air pollutants and greenhouse gases. For example, if a scenario is specified only as a reduction in $\mathrm{CO}_{2}$ emissions, and the least-cost way to achieve those emission reductions included less coal combustion for electricity generation, the results from MARKAL would include the reductions in emissions of $\mathrm{SO}_{2}, \mathrm{NO}_{x}$, and related air pollutants from coal combustion. Emissions from sources other than the energy sector are from the RCP (Representative Concentration Pathway) 4.5 scenario (Thomson et al., 2011). Here we describe each scenario briefly (see Fig. 1 for the emission trajectories of $\mathrm{SO}_{2}$, black carbon (BC), organic carbon (OC), $\mathrm{CH}_{4}, \mathrm{CO}, \mathrm{NO}_{x}$, alkenes, and paraffin from 2005 to 2055 ).

\subsection{Baseline (bs)}

This bs emission scenario (blue solid line in Fig. 1) is based on the US air quality regulations affecting the electricity sector and the transportation sector. For example, it includes Clean Air Interstate Rule, state-level renewable portfolio standards, the new Corporate Average Fuel Economy standard, Tier II light duty emission standards, heavy-duty engine emission standards, and diesel sulfur limits (see Akhtar et al., 2013; the details of each regulation can be found at https://www3.epa.gov/air/oarregul.html). The scenario does not assume any future air quality regulations beyond those that existed or were proposed in 2013. After 2020, there are

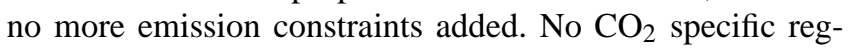
ulation, such as the Clean Power Plan, is included in this scenario, though $\mathrm{CO}_{2}$ emissions are influenced indirectly by some of the regulations included here. These regulations do not lead to a significant change in energy sources or the amount of electricity. Natural gas is added when additional electricity is needed, and coal, nuclear, and renewable electricity production remain at approximately current level. Notably, the $\mathrm{CO}_{2}$ emission rate in 2055 is almost the same as 2005 in this scenario, partly because growing energy usage due to higher demands is offset by better fuel efficiency.

\subsection{No air quality regulations (noaq)}

This noaq emission scenario (red solid line in Fig. 1) removes existing and proposed air quality regulations, which means no emission reduction strategies are present. Under this scenario, most pollutant emissions either stay similar to their 
(a) $\mathrm{SO}_{2}$

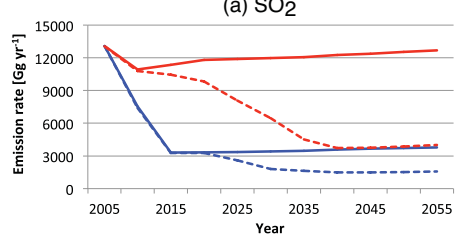

(d) $\mathrm{CH}_{4}$

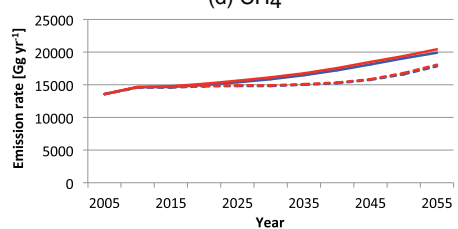

(g) Alkene

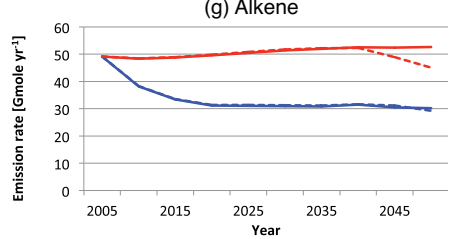

(b) $\mathrm{BC}$

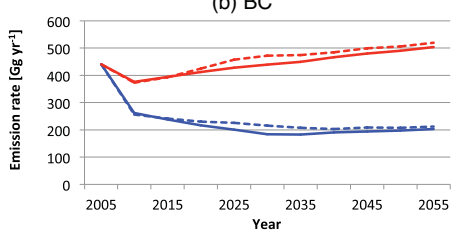

(e) $\mathrm{CO}$

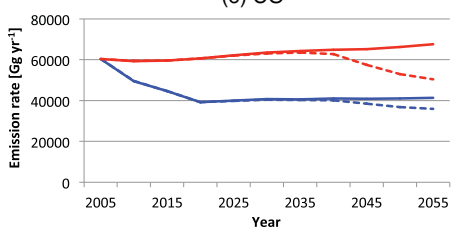

(h) Paraffin

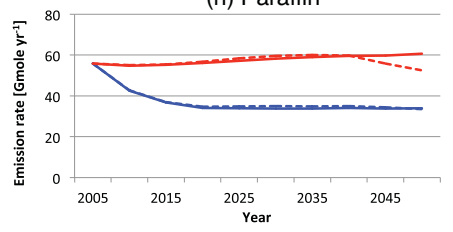

(c) $\mathrm{OC}$
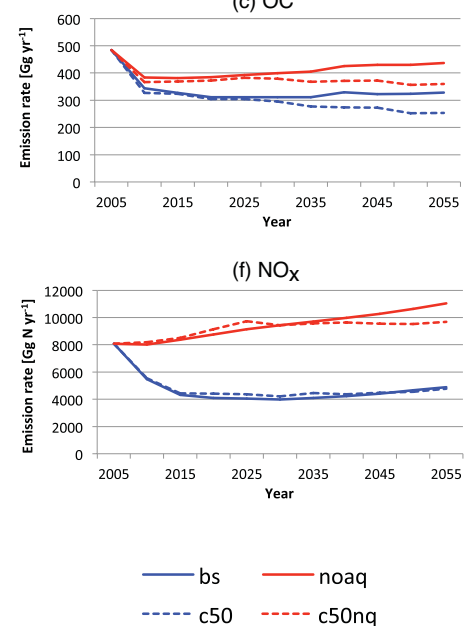

Figure 1. Emission plots of the four GLIMPSE US scenarios. See Sect. 2 for details.

2005 level or increase slightly by 2055 . Similar to the bs scenario, there is no effort to reduce $\mathrm{CO}_{2}$ emissions.

\section{$2.350 \% \mathrm{CO}_{2}$ cap in the bs scenario (c50)}

This c50 emission scenario (blue dashed line in Fig. 1) is the same as the bs scenario, but additionally includes a hypothetical climate change mitigation target, which applies a linear reduction in $\mathrm{CO}_{2}$ emissions that forces $2050 \mathrm{CO}_{2}$ emissions to be $50 \%$ of the 2005 levels (called the $50 \% \mathrm{CO}_{2}$ cap). With the $50 \% \mathrm{CO}_{2}$ cap, there are major fuel source changes in the electricity sector: switching from coal-power plants to natural gas-fired plants, applying carbon sequestration technology for all fossil fuel production, and increasing wind/solar power based on regional source availability. The $50 \% \mathrm{CO}_{2}$ cap applied in the USA contributes about $10 \%$ reduction in the global $\mathrm{CO}_{2}$ emissions of the RCP4.5 scenario in 2050.

Starting in 2020, the $50 \% \mathrm{CO}_{2}$ cap results in less $\mathrm{SO}_{2}$ and $\mathrm{OC}$ emissions but more $\mathrm{BC}$ emissions compared to the air quality regulation (i.e., the bs scenario). Note that larger BC emissions are due to increased biomass fuel usage in the residential, commercial, and industrial sectors as a bridge fuel. CO emissions are also slightly reduced, but only after 2040 .

\section{$2.450 \% \mathrm{CO}_{2}$ cap in the noaq scenario (c50nq)}

This c50nq emission scenario (red dashed line in Fig. 1) is the same as the noaq scenario, but includes the $50 \% \mathrm{CO}_{2}$ cap. This scenario also leads to significant changes in energy sources and electricity production by 2055 . For some pollutants, the impact of the $50 \% \mathrm{CO}_{2}$ cap can be quite different under the noaq scenario than the bs scenario. For instance, $\mathrm{SO}_{2}$ emissions are significantly reduced under this scenario, mainly because of retiring coal-power plants, which have high $\mathrm{SO}_{2}$ emissions. Without the air quality regulations, the $\mathrm{SO}_{2}$ emission reductions result solely from the $50 \% \mathrm{CO}_{2}$ cap, and thus occur more slowly over time than in the c50 scenario (e.g., the $\mathrm{SO}_{2}$ emission reductions reach to the bs scenario level in 2040). Except for $\mathrm{CH}_{4}$, most gas pollutant emissions deviate from the noaq scenario after around 2040.

Note that the US emission scenarios are not the same in year 2005, even though they may appear so in Fig. 1. For instance, the bs emissions are not identical to the c50 emissions in year 2005 .

\section{Model descriptions}

We used two independent aerosol models that are coupled to the same host climate model, NASA GISS ModelE2 (Schmidt et al., 2014): ModelE2-OMA (one-moment aerosol model with no aerosol microphysics) and ModelE2-TOMAS (TwO-Moment Aerosol Sectional) microphysics model. The host climate model has $2^{\circ}$ latitude by $2.5^{\circ}$ longitude resolution, with 40 vertical hybrid sigma layers from the surface to $0.1 \mathrm{hPa}(80 \mathrm{~km})$. Tracers, heat, and humidity are advected using the highly nondiffusive quadratic upstream scheme (Prather, 1986). The radiation scheme accounts for size-dependent scattering properties of clouds and aerosols based on Mie scattering (Hansen et al., 1983) and nonspherical light scattering of cirrus and dust particles based on $T$-matrix theory (Mishchenko et al., 1996). In the model, clouds are distinguished into convective and large-scale stratiform clouds. The clouds' parameterizations are similar to Del Genio (Del Genio et al., 1996; Del Genio and Yao, 1993) 
but have been improved in several respects (see details in Schmidt et al., 2006, 2014). The physics time step is $30 \mathrm{~min}$, and the radiation calculations are performed every $2.5 \mathrm{~h}$.

ModelE2-OMA uses a default aerosol module, which has no aerosol microphysics such as coagulation, condensation, and nucleation, and thus does not calculate aerosol size distributions. ModelE2-OMA simulates sulfate, carbonaceous aerosols, secondary organic aerosols, nitrate, sea salt (two size classes with a fine mode, 0.1 to $1 \mu \mathrm{m}$ in dry radii, and a coarse mode, 1 to $4 \mu \mathrm{m}$ in dry radii), and mineral dust (five size classes for clay, 0.1 and $1 \mu \mathrm{m}$ in dry radii, and four size classes for silts, 1 to $16 \mu \mathrm{m}$ in dry radii) aerosols as well as sulfur dioxide, dimethyl sulfide (DMS), methanesulfonic acid (MSA), isoprene, monoterpenes, and sesquiterpenes aerosol precursor gases (see details in Schmidt et al., 2014). Heterogeneous chemistry on the surfaces of mineral dust particles is included to form nitrate and sulfate (Bauer and Koch, 2005). Dry deposition is based on a resistance-inseries scheme, and wet deposition is determined by scavenging within and below clouds, scavenging by precipitations, and evaporation of clouds and precipitating water (Koch et al., 2006). ModelE2-OMA computes a dissolved species budget for large-scale clouds, so some sulfate formed in clouds undergoes wet scavenging without being released in air (Koch et al., 2006). Aerosol-cloud interaction is based on an empirical parameterization that computes cloud droplet number concentrations as a function of aerosol mass (Menon et al., 2002, 2008).

ModelE2-TOMAS uses a sectional aerosol microphysics approach that tracks two moments of the aerosol size distribution in each size section or "bin": total aerosol number (i.e., 0th moment) and mass (i.e., 1st mass moment). A detailed description of the TOMAS microphysics algorithm is in Adams and Seinfeld (2002) and Lee and Adams (2012). We used TOMAS with 15 bins covering $3 \mathrm{~nm}$ to $10 \mu \mathrm{m}$. Aerosol mass in each size bin is decomposed into nine aerosol species: sulfate mass, sea salt mass, mass of pure (hydrophobic) elemental carbon (EC), mass of mixed (aged) EC, mass of hydrophobic organic matter (OM), mass of hydrophilic OM, mass of mineral dust, mass of ammonium, and mass of water. In addition, the model tracks four bulk gasphase species: sulfur dioxide $\left(\mathrm{SO}_{2}\right)$, dimethylsulfide (DMS), sulfuric acid $\left(\mathrm{H}_{2} \mathrm{SO}_{4}\right)$, and a lumped gas-phase tracer that represents oxidized organic vapors forming secondary organic aerosol. TOMAS accounts for water uptake by hydrophilic OM, sulfate and sea salt. We use binary nucleation (Vehkamaki et al., 2002) with sulfuric acid concentrations reduced by 5 times and no additional boundary-layer nucleation because it tends to overpredict aerosol number concentrations in ModelE2-TOMAS (Lee et al., 2015). This might be related to overpredicted sulfur dioxide lifted into the upper and free troposphere over the Pacific Ocean in ModelE2, possibly due to overly strong convective transport, which can be oxidized to form sulfuric acid and then contribute to nucleation (Lee et al., 2015). Dry and wet deposition in
ModelE2-TOMAS are similar to those in ModelE2-OMA, but, when needed, using size-dependent processes such as gravitational settling, size-dependent resistance in the quasilaminar sublayer (Adams and Seinfeld, 2002; Seinfeld and Pandis, 1998), a modified Köhler theory for in-cloud scavenging (Pierce et al., 2007), and a modified first-order removal scheme for below-cloud scavenging (Adams and Seinfeld, 2002). For the aerosol-cloud interactions, we compute a critical supersaturation and cloud droplet number concentrations (CDNCs) using a physical-based activation parameterization from Nenes and Seinfeld (2003) with feeding a model updraft velocity that is computed based on a large-scale vertical velocity and subgrid velocity. In ModelE2-TOMAS, sizeresolved aerosol optical depth is computed using a volumeaveraged refractive index, based on Mie theory.

Both ModelE2-OMA and ModelE2-TOMAS use the same tropospheric and stratospheric gas chemistry model, which includes 156 chemical reactions among 51 gas species (Shindell et al., 2013a). In ModelE2, gas chemistry and aerosols are interactive, which means aerosol chemistry is computed with online oxidant fields (e.g., $\mathrm{H}_{2} \mathrm{O}_{2}, \mathrm{OH}$, and $\mathrm{NO}_{3}$ for sulfur aerosol; see N. Bell et al., 2005). Photolysis rates are computed using the Fast-J2 scheme, and aerosol optical depth in ModelE2-OMA affects photolysis rates (not for ModelE2-TOMAS). Ozone in the ModelE2 was previously evaluated in Shindell et al. (2013a), which found that around $900 \mathrm{hPa}$ ozone tended to be overpredicted in the model by around 5-8 ppbv. Though ozone in this version of the model was improved at higher altitudes, values near the surface were similar to the prior ModelE, which displayed little mean bias relative to a network of 40 surface ozone measurements although the correlation was only $R=0.7$ (Shindell et al., 2006). The atmospheric residence time of methane in modelE2 is in excellent agreement with the value inferred from observations, indicating that $\mathrm{OH}$ levels are also well simulated. Additional analysis of seasonal maximum 8-hourly surface ozone showed that the model captures the summertime observed levels in the western USA very well, but substantially overestimates values in eastern North America (Schnell et al., 2015).

The detailed description and evaluation of ModelE2TOMAS and the difference between OMA and TOMAS is available in Lee et al. (2015). In brief, the ModelE2TOMAS and ModelE2-OMA models capture the observed sulfur species and other aerosol species as well as aerosol optical depth mostly within a factor of 2 . However, anthropogenic aerosols in both models differ from each other by a few percent to a factor of 2 regionally, due to differences in aerosol processes such as deposition, cloud processing, and emission parameterizations.

The climate impact of each scenario is based on radiative forcing estimated using ModelE2, except for $\mathrm{CO}_{2} \mathrm{RF}$. Since ModelE2 does not simulate a carbon cycle and cannot estimate the $\mathrm{CO}_{2} \mathrm{RF}$ as result of $\mathrm{CO}_{2}$ emission changes, we use the same approach as Collins et al. (2013), which 
utilizes the $\mathrm{CO}_{2}$ impulse response function representing the multiple timescales involved in the carbon cycle as in the 2007 IPCC Assessment (Forster et al., 2007). The impulse response function characterizes the complex behavior of the climate response to $\mathrm{CO}_{2}$ emission changes as a first-order approximation. Due to the linear system assumption in the function, it has a limitation on representing nonlinear and path-dependent processes (e.g., Joos et al., 2013). However, $\mathrm{CO}_{2}$ emission changes in our scenarios are much smaller than $1 \mathrm{GtC}$ per year, whereas an impulse response function is likely in a linear regime when the $\mathrm{CO}_{2}$ impulse size is below 100 Gt C (Joos et al., 2013; Olivié and Peters, 2013). Nevertheless, in order to estimate the variation in $\mathrm{CO}_{2} \mathrm{RF}$ associated with the choice of an impulse response function, we have estimated $\mathrm{CO}_{2} \mathrm{RF}$ using additional impulse response functions derived from multi-model intercomparison projects, such as the Coupled Carbon Cycle Climate Model Intercomparison Project ( $\mathrm{C}^{4} \mathrm{MIP}$ ) and the Coupled Model Intercomparison Project Phase 5 (CMIP5), which are obtained from Olivié and Peters (2013). We found that our $\mathrm{CO}_{2} \mathrm{RF}$ differs only by $3-4 \%$ when using the impulse response functions fitted to the multi-model mean of CMIP5 and by 10$17 \%$ when using impulse response functions fitted to the multi-model mean of $\mathrm{C}^{4} \mathrm{MIP}$.

Both ModelE2-OMA and ModelE2-TOMAS have participated in various intercomparison studies for global-scale atmospheric chemistry models, such as the Atmospheric Chemistry and Climate Model Intercomparison Project (ACCMIP) and AeroCom (e.g., Lamarque et al., 2013; Lee et al., 2013; Mann et al., 2014; Naik et al., 2013; Shindell et al., 2013b).

\subsection{Simulation setup}

All simulations were performed as time slices with 3 years spin-up, targeting year 2005, 2030, and 2055. Aerosols and short-lived gases emissions were from the given time period. Three types of simulations were performed to isolate the impact due to emissions changes alone from other factors such future warm climate conditions and rapid adjustments as a result of the emission changes. A brief description of simulations is provided in Table 1 , and the detailed description is below.

In order to assess the impact of each emission scenario on air quality and climate, we set our climate model to have identical meteorology among all emission scenarios by (1) disabling the influence of aerosols and gases on radiation and clouds in the model (i.e., turning off aerosols-climate and gases-climate interactions) and (2) prescribing observed monthly mean sea surface temperatures (SSTs) and sea ice (SICE) coverage averaged from 2001 to 2010 in all FIXMET runs. We denote these simulations as FIXMET. Since the model meteorology is identical, emissions are the only contributing factor to the difference among the runs. This type of run is used here because the impact of US emissions on ra- diative forcing is likely too small to distinguish from model internal noise that can be large via clouds. We performed 3year simulations for FIXMET because the model meteorology is identical among the simulations and their year-to-year variation is small enough. Our FIXMET simulations with ModelE2-OMA were run with a newer ModelE2 version, which included some updates relative to ModelE2-TOMAS because nitrate aerosols in ModelE2-OMA were unrealistically high in the same version of ModelE2 as ModelE2TOMAS (Lee et al., 2015; Shindell et al., 2013b).

Since future warm climate alone can have a significant impact on gas pollutants (e.g., $\mathrm{O}_{3}, \mathrm{CO}, \mathrm{NO}_{x}$, and $\mathrm{CH}_{4}$ ), we ran FIXMET 2030 and 2055 simulations but with prescribed monthly mean SSTs and SICE from 2026-2034 and 2051-2059 means from ModelE2 RCP4.5 simulations, respectively. We denote these runs as FUTURE.

Finally, we ran simulations in which aerosols and gases were allowed to interact with radiation and clouds (referred to as INTERACT runs) to find out the impact of emission controls including the atmospheric response to emissions. The same SST and SICE fields used for FIXMET were also used in these simulations. With this fixed SST method, we can estimate the radiative response following "rapid" adjustments in the atmosphere due to a forcing agent. It is important to note that this method has been used to estimate aerosol effective forcing (e.g., Shindell et al., 2013b), but only allows aerosol emissions changes from the reference period. In this study, both aerosol and gas emissions are changed from the reference period (i.e., 2005) and the resulting cloud radiative forcing is also influenced by gas forcing. Thus it cannot be used to estimate aerosol effective forcing. We performed the runs for 20 years to remove the model internal noise.

The ModelE2 version used in this study does not compute $\mathrm{CH}_{4} \mathrm{RF}$ with simulated concentrations, if the $\mathrm{CH}_{4}$-radiation interactions are turned off, which is the case in the FIXMET and FUTURE simulations. Thus, we use $\mathrm{CH}_{4} \mathrm{RF}$ from the INTERACT simulations and other RFs from the FIXMET simulations in Sect. 4.3. This inconsistency would have little influence on overall RFs, since the $\mathrm{CH}_{4} \mathrm{RF}$ signal is small compared to other RFs.

\subsection{Air-quality-related mortality calculations}

We calculated the health impacts of air pollutants as premature deaths due to increased lung cancer (LC), cardiovascular disease (CVD), and respiratory disease and infections (RESP) for $\mathrm{PM}_{2.5}$ exposure, based on concentrationresponse functions (CRFs) derived from epidemiological studies. For $\mathrm{O}_{3}$ exposure, CVD and RESP are used to compute annual mortality. The change in premature deaths is calculated using Eq. (1):

$\Delta M=M_{\mathrm{b}} \times P \times \mathrm{AF}$,

where $M$ is the number of premature deaths due to $\mathrm{PM}_{2.5}$ or $\mathrm{O}_{3}, M_{\mathrm{b}}$ is the cause-specific baseline mortality rate, $P$ is 
Table 1. Summary of simulations used in this study.

\begin{tabular}{|c|c|c|c|c|c|}
\hline Run type & $\begin{array}{l}\text { Climate } \\
\text { conditions }\end{array}$ & $\begin{array}{r}\text { Emission } \\
\text { year }\end{array}$ & Model & $\begin{array}{l}\text { Length } \\
\text { of run }\end{array}$ & $\begin{array}{l}\text { Air quality and radiative } \\
\text { forcing due to }\end{array}$ \\
\hline FIXMET & 2005 & $\begin{array}{l}2005 \\
2030 \\
2055\end{array}$ & $\begin{array}{l}\text { ModelE2-OMA and } \\
\text { ModelE2-TOMAS }\end{array}$ & 3 & $\begin{array}{l}\text { aerosols and non- } \mathrm{CO}_{2} \\
\text { gases emissions }\end{array}$ \\
\hline FUTURE & $\begin{array}{l}2030 \mathrm{RCP} 4.5 \\
2055 \mathrm{RCP} 4.5\end{array}$ & $\begin{array}{l}2030 \\
2055\end{array}$ & ModelE2-OMA & 3 & $\begin{array}{l}\text { aerosols, non- } \mathrm{CO}_{2} \text { gases, } \\
\text { and GHG emissions }\end{array}$ \\
\hline INTERACT & 2005 & $\begin{array}{l}2005 \\
2030 \\
2055\end{array}$ & ModelE2-OMA & 20 & $\begin{array}{l}\text { aerosols and non- } \mathrm{CO}_{2} \text { gas } \\
\text { emissions and resulting } \\
\text { atmospheric response (rapid } \\
\text { adjustments) }\end{array}$ \\
\hline
\end{tabular}

the relevant population, and AF is the attributable fraction of premature deaths due to $\mathrm{PM}_{2.5}$ or $\mathrm{O}_{3}$ exposure, which is defined as

$\mathrm{AF}=\frac{(\mathrm{RR}-1)}{\mathrm{RR}}$,

where RR is relative risk of death from a cause-specific disease (i.e., LC, CVD, or RESP) as a result of exposure to $\mathrm{PM}_{2.5}$ or ozone increase. RRs are the main parameter estimated from epidemiological studies, but are subject to a large uncertainty.

To characterize the uncertainties in CRFs, we used three different $\mathrm{CRF}$ equations (called $\mathrm{CRF}_{\text {low,PM}}, \mathrm{CRF}_{\text {base,PM}}$, and $\mathrm{CRF}_{\text {high,PM}}$ ) to compute $\mathrm{PM}_{2.5}$-related mortality and two different equations $\left(\mathrm{CRF}_{\text {low, } \mathrm{O}_{3}}\right.$ and $\left.\mathrm{CRF}_{\text {base, } \mathrm{O}_{3}}\right)$ for $\mathrm{O}_{3}$-related mortality. For $\mathrm{PM}_{2.5}$-related mortality, we used annual mean $\mathrm{PM}_{2.5}$ concentrations that exclude sea salt and dust aerosols. Since (1) sea salt and dust aerosols are mostly naturally emitted and highly varied due to wind dependence of their emissions and (2) the toxicity of sea salt and dust particles is weaker than anthropogenic aerosols (Anenberg et al., 2012), the health impact of a policy-driven measure is obtained without them. For $\mathrm{O}_{3}$-related mortality, we used simulated hourly surface ozone concentrations for $\mathrm{CRF}_{\text {low, } \mathrm{O}_{3}}$ and $\mathrm{CRF}_{\text {high, } \mathrm{O}_{3}}$. We summarize the key equations and parameters for each CRF below and in Table 2 .

Our $\mathrm{CRF}_{\text {base }}\left(\mathrm{CRF}_{\text {base,PM }}\right.$ and $\left.\mathrm{CRF}_{\text {base, } \mathrm{O}_{3}}\right)$ method is based on case 1 in Anenberg et al. (2012), which computes $\mathrm{RR}$ using $\exp (\beta \Delta C)$, where $\beta$ is the estimated slope of the log-linear relationship between $\mathrm{PM}_{2.5}$ or $\mathrm{O}_{3}$ and premature deaths, and $\Delta C$ is the change in $\mathrm{PM}_{2.5}$ or $\mathrm{O}_{3}$. The $\mathrm{CRF}_{\text {base,PM }}$ is based on long-term RR derived from an American Cancer Society (ACS) cohort study (Pope et al., 2002); every $10 \mu \mathrm{g} \mathrm{m}^{-3}$ increase in $\mathrm{PM}_{2.5}$ is associated with 14 and $9 \%$ increases in LC and CVD/RESP mortality, respectively. However, Anenberg et al. (2012) increase the RRs from Pope et al. (2002) by 1.8 to scale up to the mean of the expert elicitation (Roman et al., 2008). Epidemiological studies indicate that the CRF slope derived from US data is log-linear over the concentration range up to $30-40 \mu \mathrm{g} \mathrm{m}^{-3}$ (Krewski et al., 2009; Laden et al., 2006). This suggests that the $\mathrm{CRF}_{\text {base,PM }}$ (i.e., log-linear CRF) might be most appropriate for the USA. For $\mathrm{O}_{3}, \mathrm{CRF}_{\text {base, } \mathrm{O}_{3}}$ uses long-term RR from the ACS cohort (Jerrett et al., 2009); every $10 \mathrm{ppb}$ increase in the seasonal (6month) average of $1 \mathrm{~h}$ daily maximum $\mathrm{O}_{3}$ is associated with a $4 \%$ increase in respiratory disease mortality.

The $\mathrm{CRF}_{\text {high,PM }}$ is based on case 2 in Anenberg et al. (2012), which uses a log CRF from Pope et al. (2002). In this method, prescaling $\beta$ is 0.2322 and 0.1552 for LC and CVD/RESP, respectively, following Cohen et al. (2004). These are scaled, as in the $\mathrm{CRF}_{\text {base }}$ case, by a factor of 1.8. The $\mathrm{RR}$ in $\mathrm{CRF}_{\text {high,PM }}$ is computed using changes in log of $\mathrm{PM}_{2.5}(\Delta \ln C)$. Compared to the other CRFs used here, this tends to predict larger changes in premature deaths (thus, we name it $\mathrm{CRF}_{\text {high,PM) }}$.

Our $\mathrm{CRF}_{\text {low }}\left(\mathrm{CRF}_{\text {low, } \mathrm{PM}}\right.$ and $\left.\mathrm{CRF}_{\text {low, }} \mathrm{O}_{3}\right)$ is based on Mar-

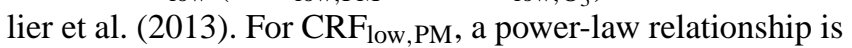
assumed between premature death and high $\mathrm{PM}_{2.5}$, including cigarette and ambient pollution, following Pope et al. (2011). The RRs for $\mathrm{PM}_{2.5}$ in this method are computed quite differently, as a function of the $\mathrm{PM}_{2.5}$ concentration rather than the concentration change; see the equations in Table 2. Note that $\mathrm{CRF}_{\text {low, } \mathrm{PM}}$ does not include $\mathrm{PM}_{2.5}$-related premature deaths caused by RESP. This CRF tends to predict the smallest change in premature deaths among the three CRFs used here. For $\mathrm{CRF}_{\text {low, }} \mathrm{O}_{3}$, a log-linear relationship is assumed between $\mathrm{O}_{3}$ and premature deaths with 1.11 for $\beta$, based on M. L. Bell et al. (2005); a 10 ppb increase in daily averaged $\mathrm{O}_{3}$ concentrations is associated with an $11 \%$ increase in cardiovascular disease mortality.

We use baseline mortality rates $\left(M_{\mathrm{b}}\right.$ in Eq. 1$)$ for all persons age 15 and older from the World Health Organization (available via http://www.who.int/healthinfo/global_burden_ disease/estimates_country_2004_2008). For all health calculations, to obtain the relevant population ( $P$ in Eq. 1), we use the year 2005 population data from the Center for International Earth Science Information Network (2005) and scale on a per country basis to obtain population for peo- 
Table 2. Concentration-response functions (CRFs) used to compute mortality due to $\mathrm{PM}_{2.5}$ and ozone. LC stands for lung cancer, CVD for cardiovascular disease, and RESP for respiratory disease and infections. See Sect. 3.2 for details.

\begin{tabular}{|c|c|c|c|c|}
\hline Species & & $\mathrm{LC}$ & CVD/RESP & Notes \\
\hline \multirow[t]{3}{*}{$\mathrm{PM}_{2.5}$} & $\mathrm{CRF}_{\text {high,PM }}$ & $\begin{array}{l}\mathrm{RR}=\exp (\beta \Delta \ln C) \\
\beta=a(=0.2322) \times 1.8\end{array}$ & $\begin{array}{l}\mathrm{RR}=\exp (\beta \Delta \ln C) \\
\beta=a(=0.1552) \times 1.8\end{array}$ & $a$ is from Chen et al. (2004) \\
\hline & $\mathrm{CRF}_{\text {base,PM }}$ & $\begin{array}{l}\mathrm{RR}=\exp (\beta \Delta C) \\
\beta=\log (1.14) / 10 \times 1.8\end{array}$ & $\begin{array}{l}\mathrm{RR}=\exp (\beta \Delta C) \\
\beta=\log (1.09) / 10 \times 1.8\end{array}$ & $\begin{array}{l}\text { The division by } 10 \text { is to apply numbers } \\
\text { derived for } 10 \mu \mathrm{g} \mathrm{m}^{-3} \text { changes of } \mathrm{PM}_{2.5} \\
\text { to } 1 \mu \mathrm{g} \mathrm{m}^{-3} \text { changes. }\end{array}$ \\
\hline & $\mathrm{CRF}_{\text {low, } \mathrm{PM}}$ & $\begin{array}{l}\mathrm{RR}=1+0.3195 \times(\operatorname{lnh} \times C)^{0.7433} \\
\text { Inh is the inhalation rate } \\
\left(18 \mathrm{~m}^{-3} \text { day }^{-1}\right)\end{array}$ & $\begin{array}{l}\mathrm{RR}=1+0.2685 \times(\operatorname{lnh} \times C)^{0.2730} \\
\mathrm{Inh} \text { is the inhalation rate } \\
\left(18 \mathrm{~m}^{-3} \text { day }^{-1}\right)\end{array}$ & $\begin{array}{l}\text { (1) Instead of } \Delta C \text {, total concentration, } \\
C \text {, } \\
\text { is used. } \\
\text { (2) RESP is not included. }\end{array}$ \\
\hline \multirow[t]{2}{*}{ Ozone } & $\mathrm{CRF}_{\text {base, }} \mathrm{O}_{3}$ & - & $\begin{array}{l}\mathrm{RR}=\exp (\beta \Delta C) \\
\beta=\log (1.04) / 10\end{array}$ & $\begin{array}{l}\text { (1) The division by } 10 \text { is to apply } \\
\text { numbers derived for } 10 \mathrm{ppb} \text { changes of } \\
\text { ozone to } 1 \mathrm{ppb} \text { changes. } \\
\text { (2) Seasonal (6-month) maxima of daily } \\
1 \mathrm{~h} \text { maxima ozone are used. } \\
\text { (3) Only RESP is included. }\end{array}$ \\
\hline & $\mathrm{CRF}_{\text {low }, \mathrm{O}_{3}}$ & - & $\begin{array}{l}\mathrm{RR}=\exp (\beta \Delta C) \\
\beta=1.11 / 10 \text { for cardiovascular } \\
\text { disease } \\
\beta=0.47 \text { for respiratory infections }\end{array}$ & $\begin{array}{l}\text { (1) } \Delta C \text { is the change in daily } \mathrm{O}_{3} \text {. } \\
\text { (2) The division by } 10 \text { is for increase in } \\
\text { RR per a } 10 \mathrm{ppb} \text {. }\end{array}$ \\
\hline
\end{tabular}

ple age 30 or older, based on United Nations Population Division (2011) estimates. This inconsistency in age limit (ages $15+$ in $M_{\mathrm{b}}$ vs. $30+$ in $P$ ) is inevitable due to the coarseness of age categories in the mortality data, but any bias from this inconsistency is expected to be small compared to the differences across CRFs. We would like to mention that our health impacts can be computed with future populations, scaled by country from the 2015 gridded population using a medium fertility scenario (United Nations Population Division, 2011). In this study, we confine the mortality change to air quality causes, rather than population changes, so year 2005 population data are used for all cases. Economic impacts can also be computed, but are not shown in this paper.

As the horizontal resolution in our model is relatively coarse, we redistribute the $\mathrm{BC}$ and $\mathrm{OM}$ components of simulated $\mathrm{PM}_{2.5}$ output in a model $2 \times 2.5$ grid cell onto a $0.5 \times 0.5$ grid, using a subgrid parameterization of urban/rural differences developed by the European Commission's Joint Research Center. This approach has been used in previous studies (Anenberg et al., 2012; Shindell et al., 2011, 2012). The downscaled surface $\mathrm{PM}_{2.5}$ was used to estimate the PM-related mortality rate.

\section{Impact of the air quality regulations and $\mathrm{CO}_{2}$ reduction policy}

We estimate the changes in air quality and radiative forcing due to the US air quality regulations and a hypothetical $\mathrm{CO}_{2}$ reduction target, using the FIXMET runs (see Table 3 for our method). The changes from the FIXMET runs are entirely due to the emissions and do not include any impact of the rapid atmospheric adjustments due to the emissions or future warming climate conditions. We present the results from 2030 and 2055 simulations relative to the 2005 simulations, as indicated in Table 3, i.e., 2030-2005 and 2055-2005. We use acronyms for simulations used to assess the impact of the air quality regulations and $\mathrm{CO}_{2}$ reduction policy: the simulations used to obtain the impact of the air quality regulation in 2030 and 2055 are denoted as AQ30 and AQ55, respectively, for the impact of $\mathrm{CO}_{2}$ reduction policy in the presence of the air quality regulations as $\mathrm{CO}_{2} 30$ and $\mathrm{CO}_{2} 55$, for the impact of $\mathrm{CO}_{2}$ reduction policy in the absence of air quality regulations as $\mathrm{CO}_{2} \mathrm{NQ} 30$ and $\mathrm{CO}_{2} \mathrm{NQ55}$, and for the impact of both air quality regulation and $\mathrm{CO}_{2}$ reduction policy as BOTH30 and BOTH55 (see Table 3 for the exact pair of simulations used for each case). We performed the FIXMET runs with ModelE2-OMA and ModelE2-TOMAS. Since the emission perturbation is over the USA, we mainly examine a change over the USA. It is important to mention that all 50 states are used for air quality and public health estimates but only 48 states excluding Alaska and Hawaii for radiative forcing. The magnitudes of air quality and mortality rate changes are larger when excluding Hawaii and Alaska, as the two states have relatively clean air.

\subsection{Air pollution}

Air pollution is mainly examined using the simulated $\mathrm{PM}_{2.5}$, $\mathrm{CO}, \mathrm{O}_{3}$, and $\mathrm{NO}_{x}$ in the model surface air. Along with total $\mathrm{PM}_{2.5}$, we also present a chemical composition of $\mathrm{PM}_{2.5}$ 
Table 3. Pair of the FIXMET simulations used to compute the impact of policies. In the Simulations column, the first letters represent the US emission scenarios and the last two numbers represent the emission year (bs for the baseline, noaq for the no air quality regulations, c50 for the $50 \% \mathrm{CO}_{2}$ cap in the baseline, and c50nq for the $50 \% \mathrm{CO}_{2}$ cap in the noaq scenario).

\begin{tabular}{|c|c|c|c|}
\hline Impact of & Simulations & \multicolumn{2}{|c|}{ Short name } \\
\hline Air quality regulation & $\begin{array}{l}(\text { bs } 30-\text { bs } 05)-(\text { noaq30-noaq05) } \\
(\text { bs55-bs05) }-(\text { noaq55-noaq05) }\end{array}$ & AQ30 & AQ55 \\
\hline $\mathrm{CO}_{2}$ reduction policy & $\begin{array}{l}(\mathrm{c} 5030-\mathrm{c} 5005)-(\mathrm{bs} 30-\mathrm{bs} 05) \\
(\mathrm{c} 5055-\mathrm{c} 5005)-(\mathrm{bs} 55-\mathrm{bs} 05)\end{array}$ & $\mathrm{CO}_{2} 30$ & $\mathrm{CO}_{2} 55$ \\
\hline $\begin{array}{l}\mathrm{CO}_{2} \text { reduction policy w/o } \\
\text { air quality regulation }\end{array}$ & $\begin{array}{l}(\mathrm{c} 50 \mathrm{nq} 30-\mathrm{c} 50 \mathrm{nq} 05)-(\text { noaq30-noaq05) } \\
(\mathrm{c} 50 \mathrm{nq} 55-\mathrm{c} 50 \mathrm{nq} 05)-(\text { noaq55-noaq05) }\end{array}$ & $\mathrm{CO}_{2} \mathrm{NQ} 30$ & $\mathrm{CO}_{2} \mathrm{NQ} 55$ \\
\hline Air quality regulation and & $(\mathrm{c} 5030-\mathrm{c} 5005)-($ noaq30-noaq05) & ВОТН30 & BOTH55 \\
\hline $\mathrm{CO}_{2}$ reduction policy & $(\mathrm{c} 5055-\mathrm{c} 5005)-($ noaq55-noaq05) & & \\
\hline
\end{tabular}
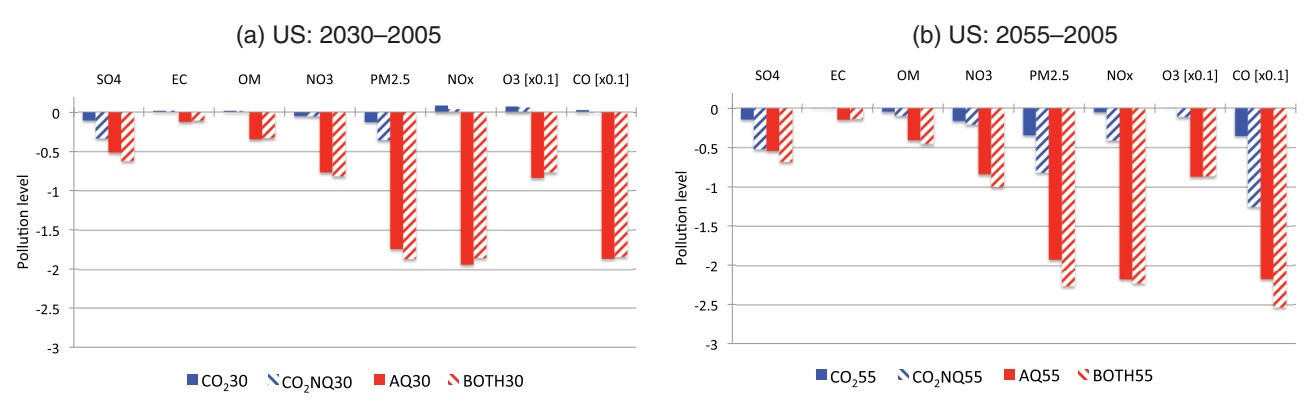

Figure 2. Changes in the US mean air pollution in 2030 and 2055 with respect to 2005 due to the air quality regulations and $\mathrm{CO}_{2}$ reduction policy (averaged over the 50 US states). All PM has a unit of $\mu \mathrm{g} \mathrm{m}^{-3}$, and gases have a unit of ppb. $\mathrm{O}_{3}$ and $\mathrm{CO}$ are multiplied by 0.1 to plot in the same $y$ axis scale as others. See Table S2 in the Supplement for the exact values.

such as sulfate (SU), black carbon (BC), organic matter $(\mathrm{OM})$, and nitrate $\left(\mathrm{NO}_{3}\right)$. Using the model surface air pollutant concentrations, PM-related and ozone-related mortality rates are computed.

We examine the impact of the air quality regulations and $\mathrm{CO}_{2}$ reduction policy on air pollution using US averages (Fig. 2) and a spatial distribution over the globe (Fig. 3). Since no more emission constraints are added after 2020, impacts on air quality in 2030 and 2055 are quite similar (see Figs. 1 and 2). Due to this, Fig. 3 presents only the 2030 2005 cases. To emphasize the future air quality changes over the USA in 2030 and 2055, the 2005 baseline air quality level (i.e., bs05 run) is used as a reference (see Table 4). In other words, the impact of policies is divided by the bs 05 air quality level (e.g., AQ30/bs05); the bs05 level is presented in Table S1 in the Supplement.

Figures 2 and 3 show a large improvement in US air quality in 2030 and 2055 due to the air quality regulations (i.e, AQ30, AQ55, BOTH30, and BOTH55). For PM 2.5 in Fig. 2, the air quality regulations lead to about $1.5-2.5 \mu \mathrm{g} \mathrm{m}^{-3}$ reduction in 2030 and 2055, which is about $20-25 \%$ of the bs05 $\mathrm{PM}_{2.5}$ concentrations. All aerosol types (SU, BC, OM, and $\mathrm{NO}_{3}$ ) are reduced by roughly $30-60 \%$ of the bs 05 level. Due to the air quality regulations, surface $\mathrm{PM}_{2.5}$ is reduced over the continental USA (especially eastern USA) and neighboring areas significantly and somewhat slightly over Eurasia (0.01-0.1 $\mu \mathrm{g} \mathrm{m}^{-3}$ ) due to less long-range transport of US-origin PM and PM precursor gases. Gas pollutants such as $\mathrm{O}_{3}$, VOC, $\mathrm{NO}_{x}$, and $\mathrm{CO}$ are also effectively reduced: on average in the USA, $\sim 8 \mathrm{ppb}$ for surface $\mathrm{O}_{3}(\sim 15 \%$ of the bs05 level); $\sim 2 \mathrm{ppb}$ for $\mathrm{NO}_{x}(60-70 \%$ of the bs05 level); $\sim 20-25 \mathrm{ppb}$ for $\mathrm{CO}(\sim 10 \%$ of the bs05 level). The spatial distributions reveal that $\mathrm{NO}_{x}$ changes are mostly localized over North America but $\mathrm{O}_{3}$ and $\mathrm{CO}$ are reduced more than $1 \mathrm{ppb}$ throughout the Northern Hemisphere (NH) due to the longer lifetime of these pollutants.

For the $\mathrm{CO}_{2}$ reduction policy (i.e., $\mathrm{CO}_{2} 30, \mathrm{CO}_{2} 55$, $\mathrm{CO}_{2} \mathrm{NQ30}$, and $\mathrm{CO}_{2} \mathrm{NQ55}$ ), impacts on air pollution are more complex than those of the air quality regulations. Firstly, except for $\mathrm{SO}_{4}$, most pollutants show a distinct spatial pattern driven by emissions, i.e., increasing concentrations over the southeastern USA and decreasing concentrations over the northwestern USA. The changes in energy sources under the $\mathrm{CO}_{2}$ policy differ by each region (depending on regionally specific conditions). For instance, the increases over the south central US states can be explained by the increases in energy production. In 2030, these US states reduce their coal usage, and the adoption of renewable energy such as solar and wind power happens after 2030. Thus, $\mathrm{SO}_{4}$ is the only air pollutant strongly reduced under the $\mathrm{CO}_{2}$ reduction policy in 2030 over the south central USA. Secondly, since the $\mathrm{CO}_{2}$ emissions are gradually reduced until 
Air Quality Regulation (AQ30): 2030-2005

(a) $\mathrm{SO}_{4}$

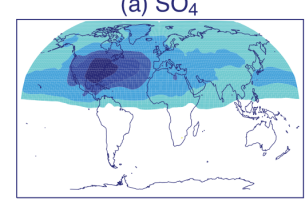

(e) PM2.5

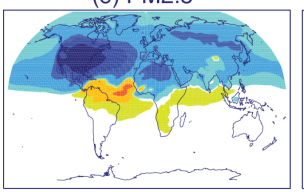

(b) $\mathrm{BC}$

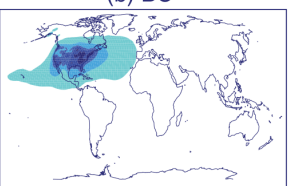

(f) $\mathrm{NOx}[\mathrm{ppb}]$

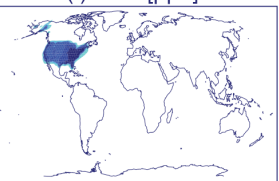

$\mathrm{CO}_{2}$ reduction policy $\left(\mathrm{CO}_{2} 30\right): 2030-2005$

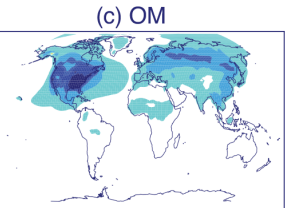

(g) $\mathrm{O}_{3}[\mathrm{ppb}]$
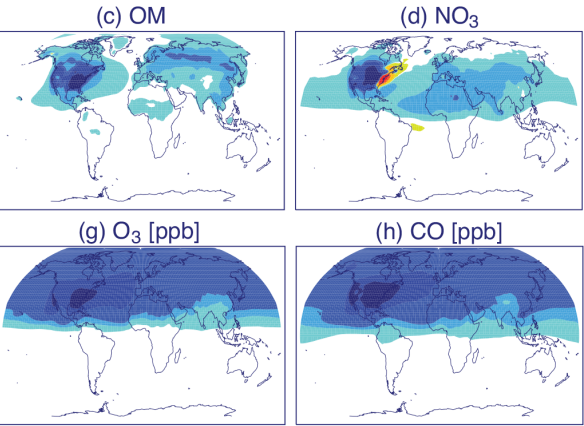

(h) $\mathrm{CO}[\mathrm{ppb}]$

(j) $\mathrm{BC}$
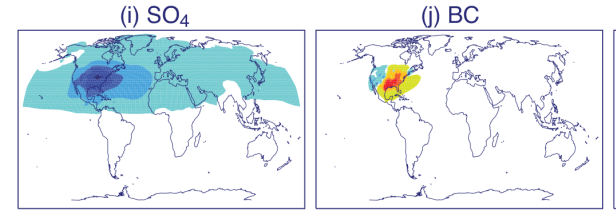

(k) OM

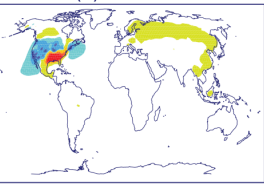

(o) $\mathrm{O}_{3}[\mathrm{ppb}]$

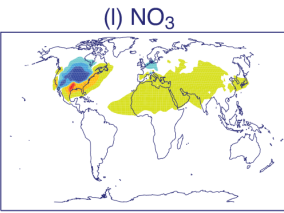

(m) PM2.5

(n) NOx [ppb]
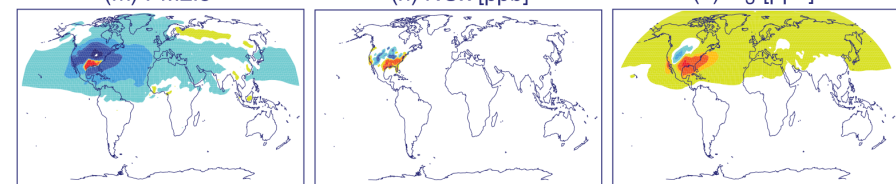

(p) $\mathrm{CO}[\mathrm{ppb}]$

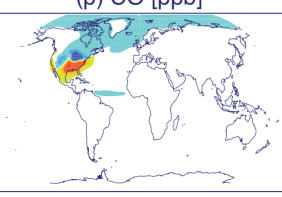

$\begin{array}{llllllllll}-0.50 & -0.10 & -0.05 & -0.01 & -0.001 & 0.001 & 0.01 & 0.05 & 0.10 & 0.50\end{array}$

PM $[\mu \mathrm{g} \mathrm{m} \cdot 3]$

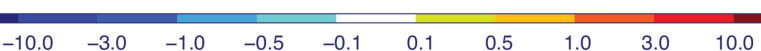

Gas [ppb]

Figure 3. Spatial distributions of changes in surface PM and gas pollutants' concentrations due to the impact of (a-h) the air quality regulations (AQ30) and (i-p) the $\mathrm{CO}_{2}$ reduction policy $\left(\mathrm{CO}_{2} 30\right)$.

Table 4. Changes in the US mean air pollution in 2030 and 2055 with respect to 2005 (averaged over the 50 states) due to the air quality regulations and $\mathrm{CO}_{2}$ reduction policy that are divided by the model baseline 2005 (bs05) level.

\begin{tabular}{|c|c|c|c|c|c|c|c|c|c|}
\hline \multirow[t]{2}{*}{ Species } & \multirow{2}{*}{$\begin{array}{r}\text { bs05 level } \\
\left(\mu \mathrm{g} \mathrm{m}^{-3} \text { or } \mathrm{ppb}\right)\end{array}$} & \multicolumn{4}{|c|}{$(2030-2005) / \mathrm{bs} 05(\%)$} & \multicolumn{4}{|c|}{$(2055-2005) / \mathrm{bs} 05(\%)$} \\
\hline & & $\mathrm{CO}_{2} 30$ & $\mathrm{CO}_{2} \mathrm{NQ} 30$ & AQ30 & ВОТН 30 & $\mathrm{CO}_{2} 55$ & $\mathrm{CO}_{2} \mathrm{NQ} 55$ & AQ55 & BOTH55 \\
\hline $\mathrm{PM}_{2.5}$ & 8.5 & -1.5 & -4.2 & -20.4 & -21.9 & -4.1 & -9.6 & -22.6 & -26.6 \\
\hline $\mathrm{SO}_{4}$ & 1.2 & -9.2 & -28.9 & -44.4 & -53.6 & -12.3 & -45.2 & -46.8 & -59.1 \\
\hline $\mathrm{EC}$ & 0.25 & 6.4 & 6.6 & -50.2 & -43.8 & 2.2 & 3.3 & -59.0 & -56.8 \\
\hline $\mathrm{OM}$ & 1.3 & 1.2 & 1.0 & -27.0 & -25.9 & -3.7 & -7.7 & -31.9 & -35.6 \\
\hline $\mathrm{NO}_{3}$ & 1.4 & -3.6 & -3.9 & -54.5 & -58.1 & -11.6 & -14.8 & -59.8 & -71.4 \\
\hline $\mathrm{NO}_{x}$ & 3.2 & 2.6 & 1.1 & -61.2 & -58.6 & -1.6 & -13.0 & -68.9 & -70.5 \\
\hline $\mathrm{O}_{3}$ & 57 & 1.2 & 1.0 & -14.6 & -13.4 & 0.1 & -2.0 & -15.2 & -15.1 \\
\hline $\mathrm{CO}$ & 174 & 0.1 & 0.0 & -10.7 & -10.6 & -2.0 & -7.2 & -12.5 & -14.5 \\
\hline
\end{tabular}

2050, larger impacts are predicted in 2055 than 2030. Also, the changes in an air pollutant are not always the same between 2030 and 2055, in terms of magnitude and sign of the changes. Ozone is initially increased slightly in 2030 but then decreased in 2055, following the emissions trend of the precursor gases $\left(\mathrm{NO}_{x}, \mathrm{CO}\right.$ and VOC) (Fig. 1). However, the changes in $\mathrm{O}_{3}$ by the $\mathrm{CO}_{2}$ policy are quite small. For surface $\mathrm{PM}_{2.5}$, it is reduced both in 2030 and 2055, mainly due to $\mathrm{SO}_{2}$ emission reductions via the fuel switch from coal to renewable energy resources. Interestingly, despite the expected anti-correlation between nitrate and sulfate formation via thermodynamics, nitrate is reduced along with sulfate possibly because of the stronger influences of $\mathrm{NO}_{x}$ emissions reductions (in Fig. 3, the spatial distribution of nitrate closely follows that of $\mathrm{NO}_{x}$ ). Lastly, impacts of measures targeting $\mathrm{CO}_{2}$ on air quality are larger in the absence of the air 
(a) US: 2030-2005

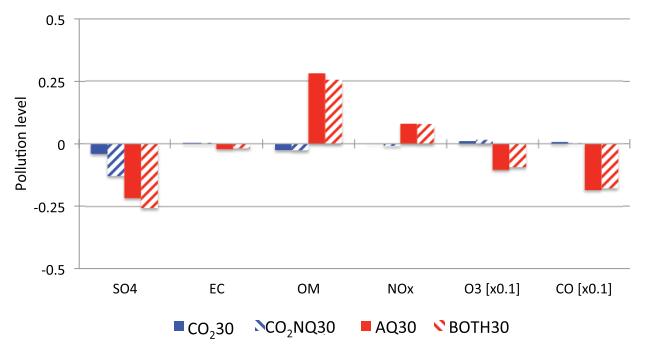

(b) US: 2055-2005

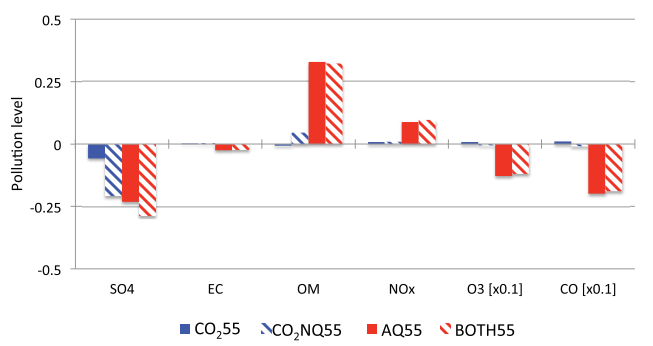

Figure 4. Same as Fig. 2 but for the difference between ModelE2-TOMAS and ModelE2-OMA. See Table S3 in the Supplement for the exact values for ModelE2-TOMAS.

quality regulations (i.e., $\mathrm{CO}_{2} \mathrm{NQ}$ ), because using less coal reduces $\mathrm{SO}_{2}$ emissions effectively without the air quality regulations. For instance, when the air quality regulations are applied (i.e., $\mathrm{CO}_{2} 30$ and $\mathrm{CO}_{2} 55$ ), the US averaged $\mathrm{PM}_{2.5}$ concentration is reduced by $0.13-0.34 \mu \mathrm{g} \mathrm{m}^{-3}$ (about $1-5 \%$ of the bs05 level), mainly driven by sulfate reduction. Without the air quality regulation (i.e., $\mathrm{CO}_{2} \mathrm{NQ} 30$ and $\mathrm{CO}_{2} \mathrm{NQ55}$ ), $\mathrm{PM}_{2.5}$ is reduced by $0.36-0.81 \mu \mathrm{g} \mathrm{m}{ }^{-3}$ (about $5-10 \%$ of the bs05 level). To be clear, the absolute pollution level is higher in the $\mathrm{CO}_{2} \mathrm{NQ}$ cases than the $\mathrm{CO}_{2}$ cases. In the case of $\mathrm{O}_{3}$ in 2055 , the $\mathrm{CO}_{2} \mathrm{NQ} 55$ case shows a reduction $(-1.1 \mathrm{ppbv})$ while the $\mathrm{CO}_{2} 55$ case shows a slight increase $(+0.03$ ppbv). The same pattern is also observed in ModelE2-TOMAS.

The results presented above are based on ModelE2-OMA. Using ModelE2-TOMAS aerosol microphysics model, we observe similar changes in air pollutions by the air quality regulations and $\mathrm{CO}_{2}$ reduction policy (see Fig. 4). However, there are some differences in the magnitudes of their $\mathrm{PM}_{2.5}$ changes, largely due to missing nitrate aerosols in ModelE2TOMAS (only ModelE2-OMA simulates nitrate particles). Besides the nitrates, ModelE2-TOMAS tends to simulate more sulfate reduction and less OM reduction. These effects cancel each other and overall $\mathrm{PM}_{2.5}$ difference between the models is almost equivalent to the amount of nitrate shown in Fig. 2. The changes in gas pollutants are very similar between the models, as the same gas chemistry module is used for both models.

\subsection{Health impacts}

Figure 5 shows the number of prevented $\mathrm{PM}_{2.5}$-related premature deaths in the USA due to LC, CVD, and RESP by the impact of the air quality regulations and $\mathrm{CO}_{2}$ reduction policy. Based on $\mathrm{CRF}_{\text {base,PM}}$, the $\mathrm{PM}_{2.5}$ reduction with the air quality regulations prevents about 74200 and 78500 deaths over the USA in 2030 and 2055, respectively. For the $\mathrm{CO}_{2}$ reduction policy, about 5500 and $19600 \mathrm{PM}_{2.5}$-related deaths are avoided in 2030 and 2055, respectively. Since the $\mathrm{CO}_{2}$ policy improves air quality more significantly in later years, the prevented deaths in 2055 are much larger than that in 2030. As discussed in Sect. 4.1, the relative impact of the
$\mathrm{CO}_{2}$ reduction policy on air quality is larger without the air quality regulations (i.e., $\mathrm{CO}_{2} \mathrm{NQ} 30$ and $\mathrm{CO}_{2} \mathrm{NQ55}$ ). Thus, the prevented deaths are about 2-3 times larger under the $\mathrm{CO}_{2} \mathrm{NQ}$ cases: $\sim 17100$ vs. $\sim 5500$ in 2030 and $\sim 36100$ vs. $\sim 19600$ in 2055 . We find that there is about an order of magnitude of difference in the total mortality rate between $\mathrm{CRF}_{\text {low,PM }}$ and $\mathrm{CRF}_{\text {high, } \mathrm{PM}}$, indicating large uncertainties in CRF methods. However, all CRF cases show that CVD is the major contributor to overall $\mathrm{PM}_{2.5}$-related mortality, and the contributions by LC and RESP are quite similar to each other.

The $\mathrm{O}_{3}$-related premature deaths are presented in Fig. 6 . Based on the $\mathrm{CRF}_{\text {base, } \mathrm{O}_{3}}$ method that includes only RESP, the air quality regulations prevent about 17200-18400 deaths over the USA in 2030 and 2055, while the $\mathrm{CO}_{2}$ reduction policy leads to $\sim 1600$ fewer deaths in 2030 and $\sim 400$ deaths in 2055. However, the $\mathrm{CO}_{2} \mathrm{NQ}$ case prevents $\sim 2700$ deaths in 2055, following the surface $\mathrm{O}_{3}$ trends discussed in Sect. 4.1. Compared to $\mathrm{CRF}_{\text {base, } \mathrm{O}_{3}}, \mathrm{CRF}_{\text {low, } \mathrm{O}_{3}}$ includes mortality due to CVD and overall mortality computed with this method is about a factor of 2 less. For the premature deaths owing to RESP, the two CRF methods are different by $1.5-2$ orders of magnitude.

The US mortality rates contribute global mortality rate approximately $80-90 \%$ of PM-related mortality and $30-40 \%$ for $\mathrm{O}_{3}$-related mortality (see Table $\mathrm{S} 4$ in the Supplement for the global mortality rate). Compared to PM, the benefits of controlling US ozone precursor emissions are being spread out to the NH region, as ozone is a secondary air pollutant with a longer lifetime than aerosol constituents. For AQ30, $\mathrm{CO}_{2} 30$, and $\mathrm{CO}_{2} 55$, its global distributions are presented in Fig. 7a, d, and g, respectively. Note that the spatial distribution in AQ55 is almost identical to AQ30 (not shown). The eastern USA shows the strongest changes in mortality. There are noticeable impacts over Canada, Mexico, and European and Asian countries, but no impacts on the Southern Hemisphere. Unlike $\mathrm{CO}_{2} 55, \mathrm{CO}_{2} 30$ shows increasing mortality in the southeastern USA due to the increase in $\mathrm{O}_{3}, \mathrm{BC}, \mathrm{OM}$, and $\mathrm{NO}_{3}$ aerosols (see Fig. 3).

Figure 8 shows the difference between ModelE2-TOMAS and ModelE2-OMA in overall PM-related mortality estimated from three CRF methods (i.e., ModelE2-TOMAS 
(a) US PM2.5: 2030-2005

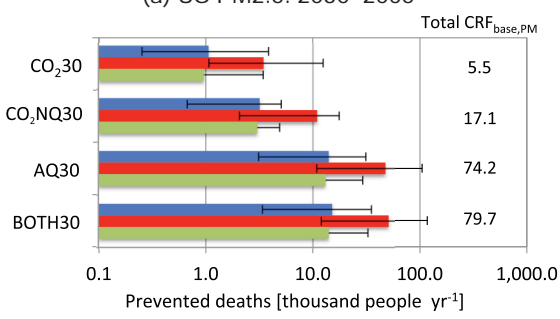

(b) US PM2.5: 2055-2005

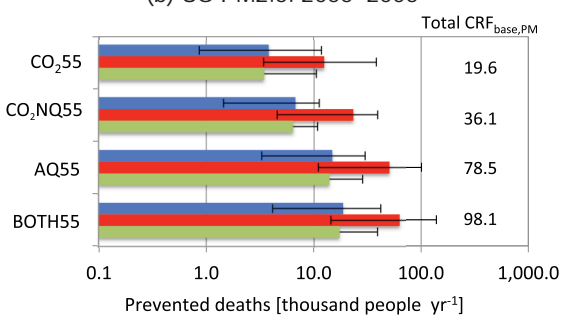

$\square$ LC $\square$ CVD $\square$ RESP

Figure 5. Impact of the air quality regulations and $\mathrm{CO}_{2}$ reduction policy on US mortality related to $\mathrm{PM}_{2.5}$. The color bar shows the mortality rate using $\mathrm{CRF}_{\text {base,PM}}$. The higher $\left(\mathrm{CRF}_{\text {high,PM}}\right)$ and lower $\left(\mathrm{CRF}_{\text {low,PM }}\right)$ bars indicate the spread in mortality change predicted using the range of concentration-response functions used in the study (see Table 2). Note that the $x$ axis is log-scale and has a unit of thousand people per year. The total mortality rate using $\mathrm{CRF}_{\text {base, } \mathrm{PM}}$ is presented on the right side.

(a) US O $: 2030-2005$

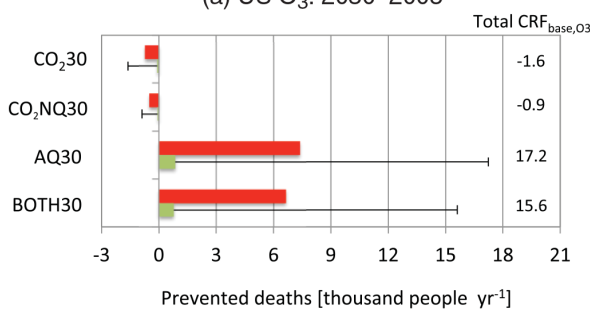

(b) US O $: 2055-2005$

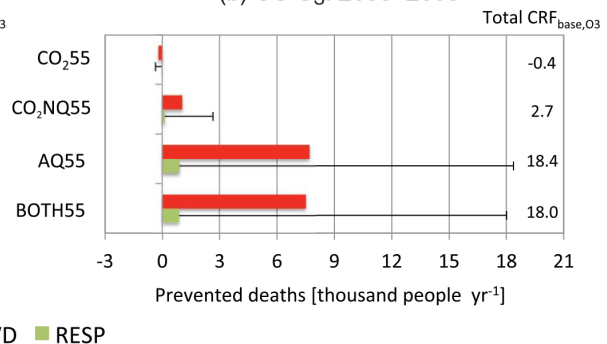

Figure 6. Impact of the air quality regulations and $\mathrm{CO}_{2}$ reduction policy on US mortality related to ozone. It is important to note that the color bar shows the mortality rate using $\mathrm{CRF}_{\text {low, } \mathrm{O}_{3}}$, and the horizontal upper bars are for mortality rates using $\mathrm{CRF}_{\text {base, } \mathrm{O}_{3}}$ because $\mathrm{CRF}_{\text {base, } \mathrm{O}_{3}}$ only includes RESP. It has a unit of thousand people per year. The total mortality rate using $\mathrm{CRF}_{\mathrm{base}, \mathrm{O}_{3}}$ is presented on the right side.

- ModelE2-OMA). The sign of mortality changes generally agrees well between the two aerosol models, but they are different in terms of the magnitudes. For instance, the $\mathrm{AQ}$ and BOTH cases with the air quality regulations result in a significantly lower number of prevented deaths in all CRF approaches using ModelE2-TOMAS: $\sim 25 \%$ fewer prevented deaths for $\mathrm{CRF}_{\text {low,PM}}$; $\sim 40 \%$ for $\mathrm{CRF}_{\text {base,PM}}$; $\sim 15 \%$ for $\mathrm{CRF}_{\text {high,PM}}$. This is due to missing nitrate aerosol in ModelE2-TOMAS, which leads to more than half of $\mathrm{PM}_{2.5}$ reduction in ModelE2-OMA. We note that the cases of $\mathrm{CO}_{2} 30$ and $\mathrm{CO}_{2} \mathrm{NQ} 55$ in Fig. 8 show inconsistent changes among the CRF approaches, which is a result of having nonlinearity in each CRF.

For the AQ30, $\mathrm{CO}_{2} 30$, and $\mathrm{CO}_{2} 55$ cases, the spatial distributions of the model differences are shown in Fig. 7. ModelE2-TOMAS tends to simulate a lower number of prevented PM-related deaths over the USA but more deaths over some parts of Eurasia, including India. For ModelE2TOMAS, despite the increase in $\mathrm{BC}$ and $\mathrm{OM}$ in the $\mathrm{CO}_{2} 30$ case, premature deaths are reduced everywhere in the USA because $\mathrm{SO}_{4}$ decrease is stronger than the combined $\mathrm{BC}$ and $\mathrm{OM}$ increase (thus, it has a different spatial pattern to ModelE2-OMA). It demonstrates how uncertainties in aerosol modeling can play an important role, emphasizing the importance of utilizing more than one aerosol model for estimating health benefits from pollutant emission controls.

\subsection{Climate impacts}

We estimate the climate impact using aerosol direct forcing (ADF), aerosol first indirect forcing (AIF), BC albedo forcing, ozone RF (radiative forcing), methane RF, and $\mathrm{CO}_{2} \mathrm{RF}$ in this study. Note that the ozone RFs are referenced at the tropopause, where they provide a better indicator of global temperature response, while the others are at the top of atmosphere. Figure 9 presents individual RF averaged over the globe as well as over the USA (48 states only) in 2030 and 2055 relative to 2005 . Note that $\mathrm{BC}$ albedo forcing is added to ADF in Fig. 9, and AIF and ozone RF are from the FIXMET runs, methane RF from the INTERACT runs, $\mathrm{CO}_{2} \mathrm{RF}$ from the simple carbon cycle model, and total RF is summed over all aerosols, ozone, methane, and $\mathrm{CO}_{2}$. The RF spatial distributions in 2030 relative to 2005 are presented in Fig. 10 for the impact of $\mathrm{CO}_{2}$ reduction policy and in Fig. 11 for the impact of the air quality regulations. The RF spatial distributions in 2055 are very similar to those in 2033 (not shown).

In the case of the impact of $\mathrm{CO}_{2}$ policy in the presence of the air quality regulation (the $\mathrm{CO}_{2}$ cases), both ADF 

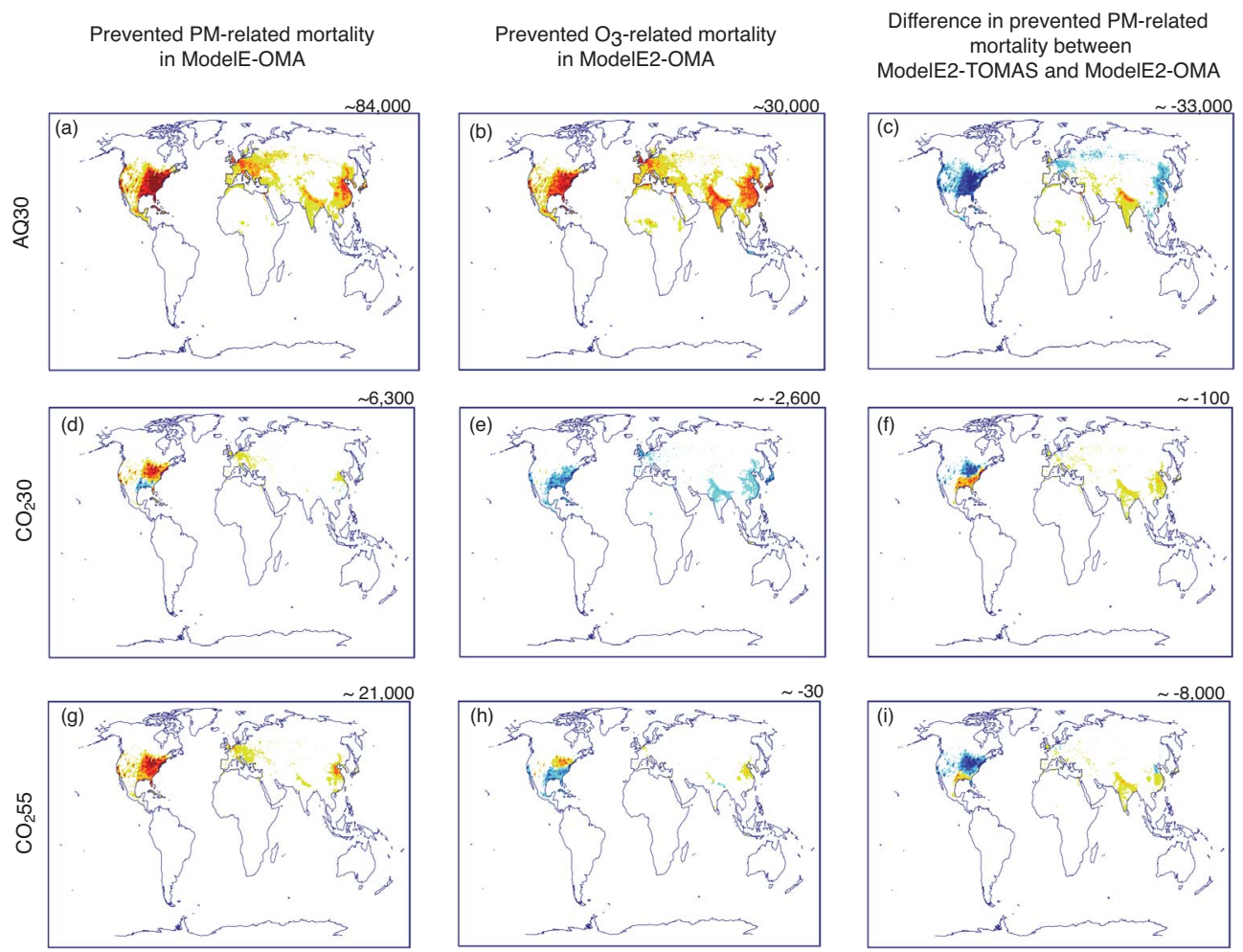

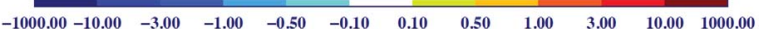

Figure 7. Global distributions of prevented PM- and $\mathrm{O}_{3}$-related mortality due to impact of (a, b) the air quality regulations in 2030 (AQ30), (d, e) $\mathrm{CO}_{2}$ reduction policy in $2030\left(\mathrm{CO}_{2} 30\right)$, and $(\mathbf{g}, \mathbf{h}) \mathrm{CO}_{2}$ reduction policy in $2055\left(\mathrm{CO}_{2} 55\right)$. The differences between two aerosol models are shown in panel (c) for AQ30, (f) for $\mathrm{CO}_{2} 30$, and (i) for $\mathrm{CO}_{2} 55$. In each panel, globally summed mortality is presented in the right upper corner.

(a) US PM2.5: 2030-2005

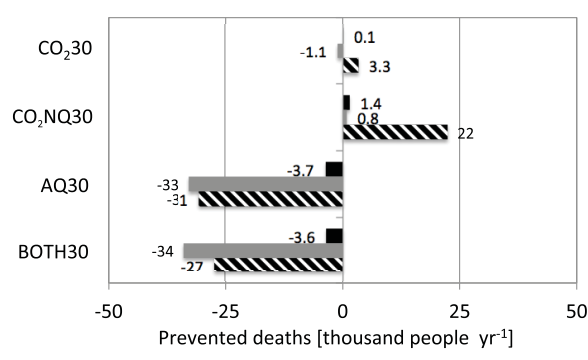

- CRFLOW U CRFBASE \CRFHIGH (b) US PM2.5: 2055-2005

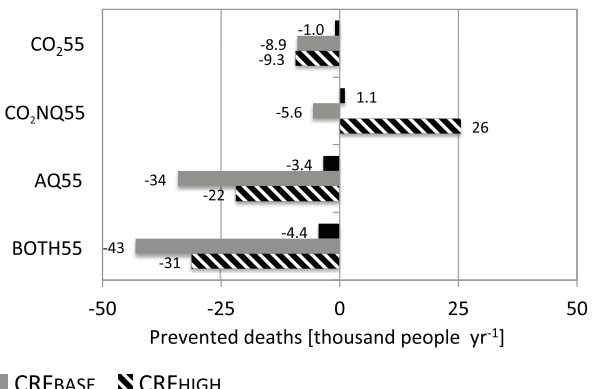

Figure 8. Same as Fig. 5 but for the difference between ModelE2-TOMAS and ModelE2-OMA.

and AIF are positive throughout the globe $\left(0.009 \mathrm{~W} \mathrm{~m}^{-2}\right.$ as the global mean) due to the reduction of light-reflecting species such as $\mathrm{SO}_{4}, \mathrm{OM}$, and $\mathrm{NO}_{3}$. The sum of ozone and methane RFs is negligible in both global and US means because their RFs are small and canceled each other. There is overall negative RF globally $\left(-0.015 \mathrm{~W} \mathrm{~m}^{-2}\right.$ in 2030 and $-0.056 \mathrm{~W} \mathrm{~m}^{-2}$ in 2055$)$ but overall positive RF over the US regions $\left(0.14 \mathrm{~W} \mathrm{~m}^{-2}\right.$ in 2030 and $0.22 \mathrm{~W} \mathrm{~m}^{-2}$ in 2055$)$ because of positive aerosol RF. The localized aerosol RF is due to its short lifetime, while the well-distributed negative $\mathrm{CO}_{2}$ RF over the globe is due to its long lifetime. The strong positive RFs from aerosols are mostly localized over the USA, especially over the eastern USA (in Fig. 10 for the 2030 case). Previous studies show a large influence of regional RF on the regional climate response (i.e., surface air temperature) over the USA (Leibensperger et al., 2012) or the NH midlatitude regions (Shindell and Faluvegi, 2009). Our regional RF over the USA is only $0.22 \mathrm{~W} \mathrm{~m}^{-2}$ in 2055 , and therefore the 
(a) Global: 2030-2005

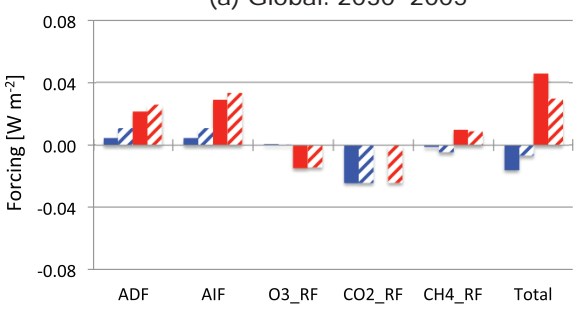

(c) US: 2030-2005

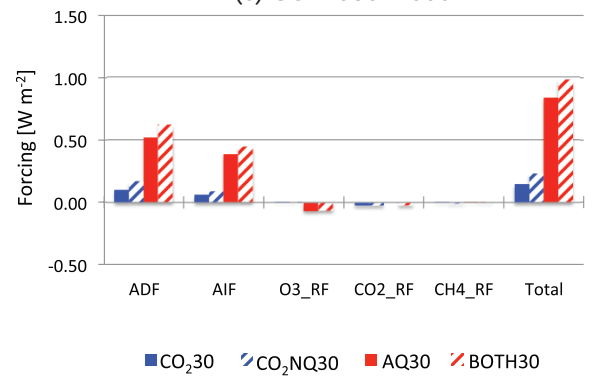

(b) Global: 2055-2005

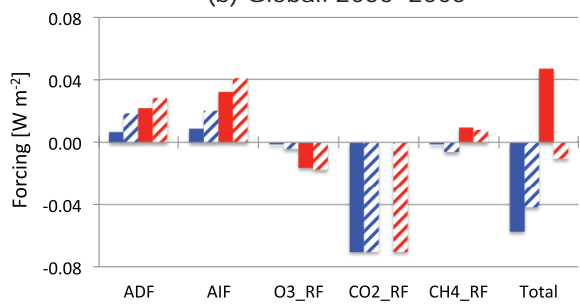

(d) US: 2055-2005

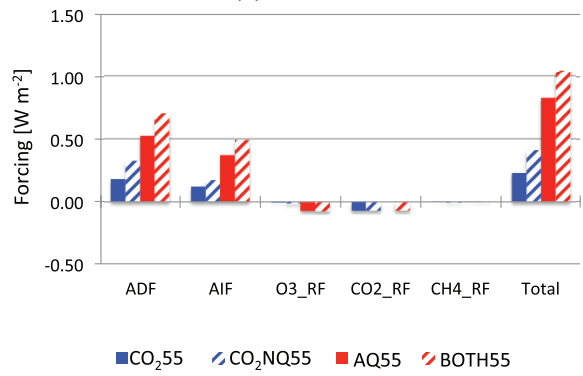

Figure 9. Impact of the air quality regulations and $\mathrm{CO}_{2}$ reduction policy on global (a, b) and US (c, d) averaged radiative forcings in 2030 and 2055 relative to 2005. Note that BC albedo forcing is added to aerosol direct forcing (ADF). The exact value of RFs is presented in Tables S5 and S6 for global mean and US mean, respectively.

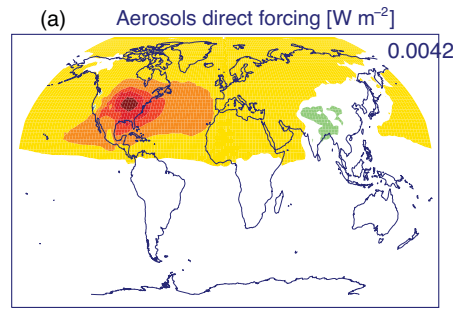

(b) Aerosol indirect forcing $\left[\mathrm{W} \mathrm{m}^{-2}\right]$

(c) Ozone Tropopause forcing $\left[\mathrm{W} \mathrm{m}^{-2}\right]$
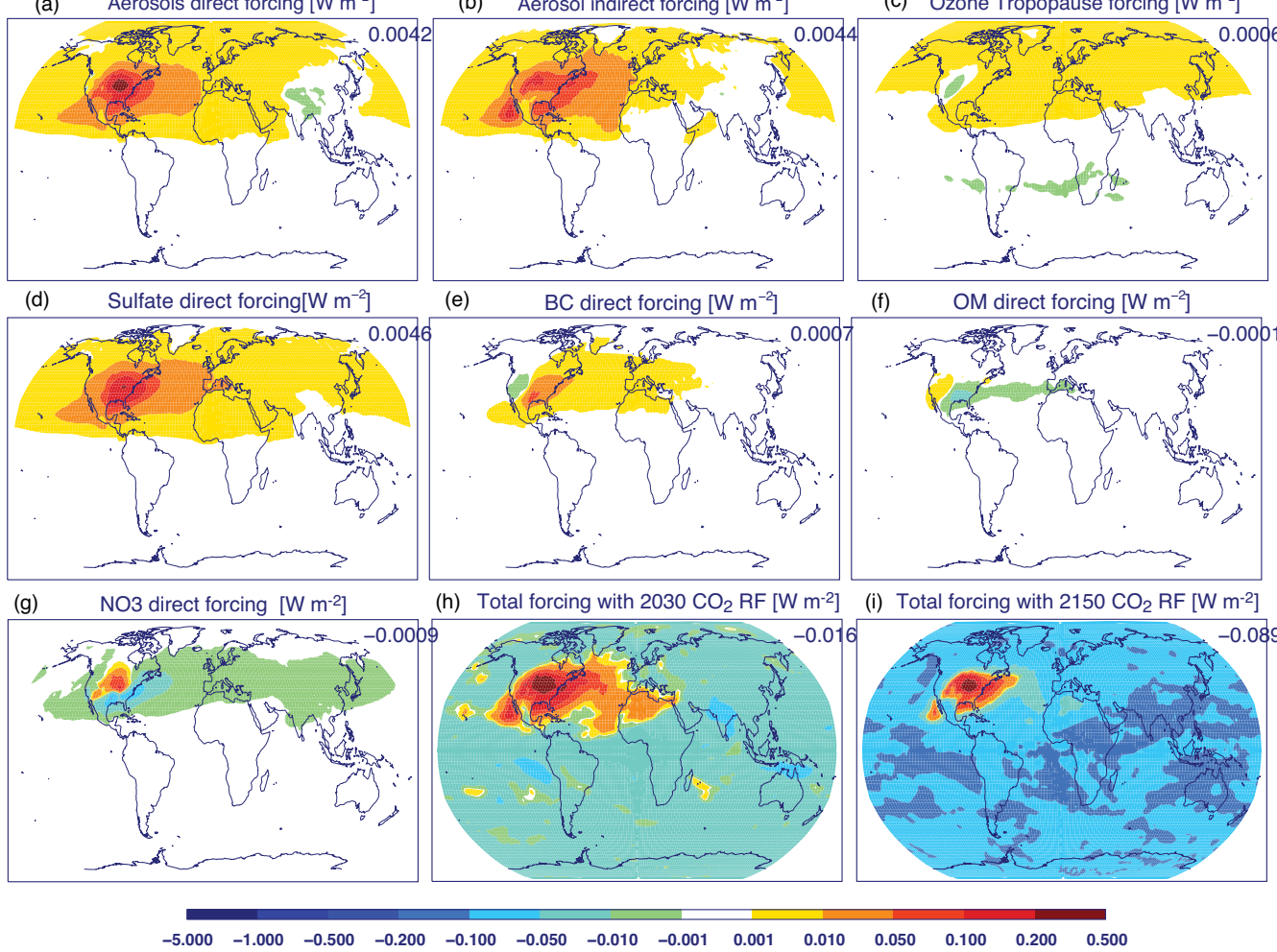

Figure 10. Impact of the $\mathrm{CO}_{2}$ reduction policy $\left(\mathrm{CO}_{2} 30\right)$ on radiative forcing in 2030 relative to 2005 . 


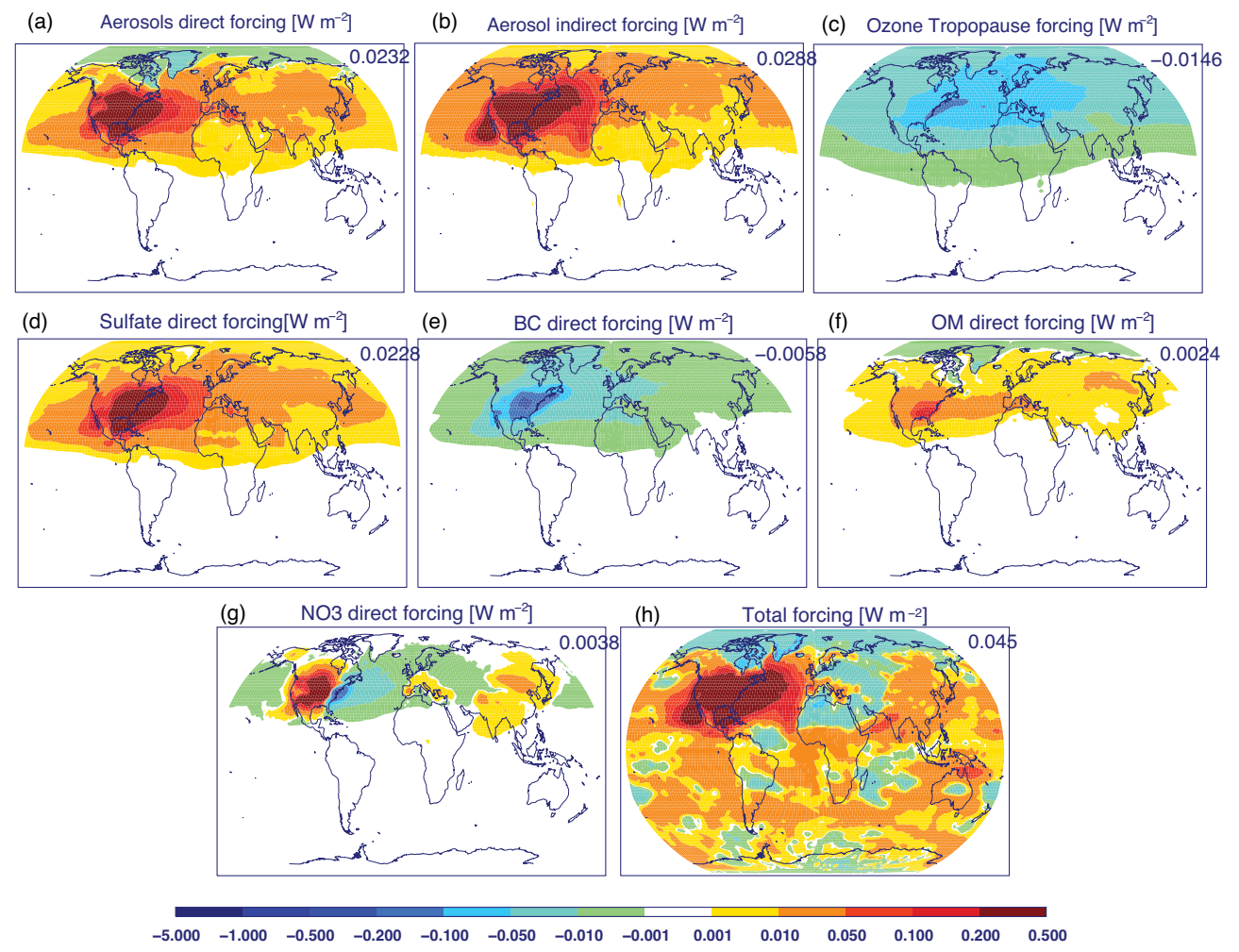

Figure 11. Impact of the air quality regulations (AQ30) on radiative forcing in 2030 relative to 2005.

resulting climate response would be small. Nevertheless it is likely to contribute to warming rather than cooling, at least in the near term; and thus the $\mathrm{CO}_{2}$ reduction policy used in our study could potentially lead to mild regional climate disbenefits over the USA, especially during the summer (Shindell et al., 2016). For the $\mathrm{CO}_{2}$ reduction policy in the absence of the air quality regulation (the $\mathrm{CO}_{2} \mathrm{NQ}$ cases), total $\mathrm{RF}$ is slightly more positive than the $\mathrm{CO}_{2}$ cases due to larger reduction in $\mathrm{SO}_{2}$ emissions.

Since the air quality regulations remove light-reflecting species more effectively than light-absorbing species without affecting $\mathrm{CO}_{2} \mathrm{RF}$, total $\mathrm{RF}$ is positive both globally $\left(0.035 \mathrm{~W} \mathrm{~m}^{-2}\right.$ in 2030 and $0.036 \mathrm{~W} \mathrm{~m}^{-2}$ in 2055$)$ and USA regionally $\left(0.83 \mathrm{~W} \mathrm{~m}^{-2}\right.$ in 2030 and $0.82 \mathrm{~W} \mathrm{~m}^{-2}$ in 2055). Note again that the impact of the air quality regulations is quite similar between 2030 and 2055, so the 2055 cases are not shown. In Fig. 11, the light-reflecting aerosols such as $\mathrm{SO}_{4}$ and $\mathrm{OM}$ show a positive $\mathrm{RF}$, and the light-absorbing species such as $\mathrm{BC}$ and $\mathrm{O}_{3}$ show a negative RF. In 2030 relative to 2005, overall ADF is positive (global mean, $0.023 \mathrm{~W} \mathrm{~m}^{-2}$; US mean, $0.55 \mathrm{~W} \mathrm{~m}^{-2}$ ) mainly due to dominant positive RF by sulfate, and AIF is also positive (global mean, $0.029 \mathrm{~W} \mathrm{~m}^{-2}$; US mean, $0.38 \mathrm{~W} \mathrm{~m}^{-2}$ ) due to reduced cloud droplet number concentrations (CDNCs). We find the US air quality regulations have a moderate impact on radiative forcing over the Atlantic Ocean and the Pacific Ocean nearby California, roughly $0.1-0.5 \mathrm{~W} \mathrm{~m}^{-2}$ in 2030 , and a mild impact throughout the $\mathrm{NH}$, roughly $0.01-0.05 \mathrm{~W} \mathrm{~m}^{-2}$. We also find that the magnitude of AIF is comparable to that of ADF, which means it is critical to include the AIF in assessment of the climate impact of an emission policy.

Compared to ModelE2-OMA, overall RF in ModelE2TOMAS tends to be less positive in most cases, which can be mainly explained by the difference in sulfate, nitrate, and aerosol indirect effects (see Fig. 12 for the US mean comparisons). The global mean and US mean RF values are presented in Tables S5 and S6 for ModelE2-OMA and Tables S7 and S8 for ModelE2-TOMAS, respectively. Given that the difference in nitrate is simply due to missing it in ModelE2TOMAS, we focus on the model difference in sulfate and AIF. Regardless of emission scenarios, ModelE2-OMA simulates more positive sulfate ADF than ModelE2-TOMAS for both global and US means. For AIF, ModelE2-OMA tends to predict more positive AIF global and US means in all scenarios except for the US mean of the $\mathrm{CO}_{2}$ and $\mathrm{CO}_{2} \mathrm{NQ}$ cases. It is worth noting that the differences of surface PM between the two aerosol models shown in Fig. 4 cannot explain the RF differences. For example, the US mean surface nitrate is reduced under these scenarios but the US mean nitrate ADF is negative. Since aerosol RFs (and aerosol optical depth) depend on a vertical distribution of aerosols and assumed aerosol optical properties, the surface PM alone is not sufficient to explain RFs. 
(a) US: 2030-2005

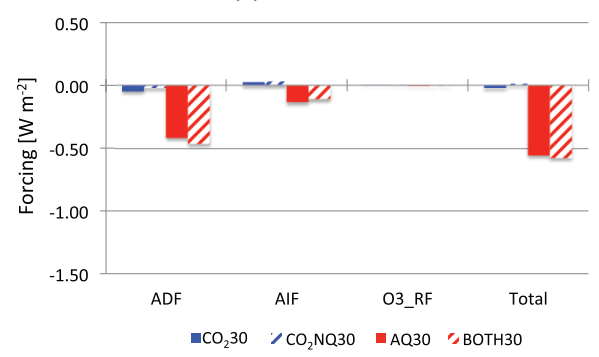

(b) US: 2055-2005

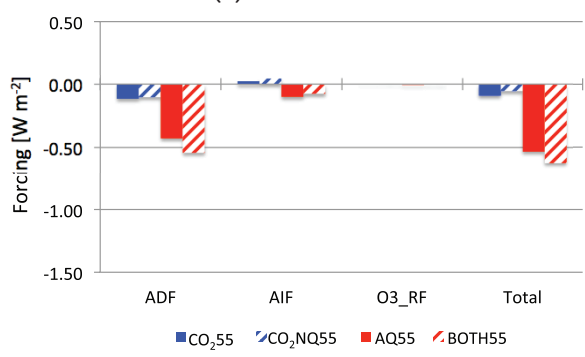

Figure 12. Same as Fig. 9 but for the difference in the US mean between ModelE2-TOMAS and ModelE2-OMA.

\section{Impact of future climate conditions and rapid adjustments}

We discover that the impact of policies on radiative forcing over the USA is affected only a little by using the future climate conditions (i.e., FUTURE runs). As shown in Fig. 13, ADF averaged over the USA (including BC albedo $\mathrm{RF}$, which is much weaker than ADF) is generally less positive than that in the FIXMET runs (shown in Fig. 9), and the changes are a few percent. US mean AIF is more strongly influenced by the future climate conditions, becoming more positive by $20-40 \%$ from the FIXMET runs. Ozone RF is changed less than $10 \%$ except for the $\mathrm{CO}_{2}$ policy cases.

Looking at the individual scenario (e.g., bs30, bs55, c5030, c5055; not by the policies), the impact of future climate conditions is quite similar among the scenarios, which lead to increase ADF (including BC albedo RF) by 0.12 $0.17 \mathrm{~W} \mathrm{~m}^{-2}$ and $\mathrm{O}_{3} \mathrm{RF}$ by $0.07-0.1 \mathrm{~W} \mathrm{~m}^{-2}$ and to a decrease of AIF by $1.9-2.1 \mathrm{~W} \mathrm{~m}^{-2}$ over the USA. The positive $\mathrm{O}_{3} \mathrm{RF}$ can be explained by increased $\mathrm{O}_{3}$ in the middle and upper troposphere (where its radiative forcing per unit change is largest) that closely follows $\mathrm{NO}_{x}$ changes, which might be explained by the fact that the lightning $\mathrm{NO}_{x}$ sources are increased by $10-14 \%$ in 2030 and 2055, compared to in 2005 . We find that surface ozone is decreased with a warmer future climate over most of the globe (including the USA) except for a few areas such as eastern Europe, India, and southeast Asia where surface ozone pollution is particularly high in the model (not shown). This suggests that future warm climates tend to lead to less ozone in most areas due to increased loss of reactive oxygen with water vapor, and more ozone in highly polluted areas related to increased thermal decomposition of peroxyacetyl nitrates, both of which are consistent with the finding by Doherty et al. (2013). There is some disagreement with the GISS GCM results presented in Doherty et al. (2013) in terms of the detailed spatial patterns of the changes in ozone pollution due to the warmer temperatures, which is not surprising given the difference in emission scenarios (year 2001 TF-HTAP emissions used for Doherty et al., 2013, whereas year 2030/2055 RCP4.5 emissions used in this study).
Using the INTERACT runs, we find that no large changes in ADF and ozone RF are found by allowing model climate/meteorology to be influenced by aerosols and gases (shown in Fig. 14). Nevertheless, we observe some systematic changes such as (a) the impact of the atmospheric rapid adjustments on $\mathrm{O}_{3} \mathrm{RF}$ being relatively large under the $\mathrm{CO}_{2}$ reduction policy (i.e., $\mathrm{CO}_{2} 30, \mathrm{CO}_{2} 55, \mathrm{CO}_{2} \mathrm{NQ} 30$, and $\mathrm{CO}_{2} \mathrm{NQ55}$ ), and (b) the relative changes being larger in $\mathrm{O}_{3} \mathrm{RF}$ than ADF. The latter is also shown in the FUTURE simulations, and this might be due to the fact that $\mathrm{O}_{3}$ is a greenhouse gas that interacts with the outgoing longwave radiations which depend on temperature, whereas the aerosols interact with only solar radiation via aerosol direct effects in our forcing calculation. For example, in the $\mathrm{CO}_{2} 30$ cases, $\mathrm{ADF}$ increases by $26 \%$, whereas $\mathrm{O}_{3} \mathrm{RF}$ decreases by 3 times. In the case of $\mathrm{AQ} 30, \mathrm{ADF}$ decreases by $8 \%$ while $\mathrm{O}_{3} \mathrm{RF}$ increases by $54 \%$. Note that AIF is not included here because the cloud radiative forcing in the INTERACT runs is also influenced by gas tracers such as ozone and methane.

\section{Conclusions}

We have investigated the impact of future US emission scenarios, based on air quality regulations and a hypothetical $\mathrm{CO}_{2}$ reduction target, on air quality, public health, and climate change. The four GLIMPSE emission scenarios developed from the US EPA are used here, which are hypothetical scenarios with and without the air quality regulations and/or a climate policy that reduces the 2005 US $\mathrm{CO}_{2}$ emissions by $50 \%$ by 2050 (see Akhtar et al., 2013). We have performed various simulations with these scenarios, using the NASA GISS ModelE2 climate model with default aerosol model (ModelE2-OMA; no aerosol microphysics model in ModelE2; Schmidt et al., 2014). To find out the uncertainties in aerosol modeling, we have used the sectional-based aerosol microphysics model (ModelE2-TOMAS; Lee et al., 2015) that was also coupled to the NASA GISS ModelE2. Since the host climate model is identical, the differences in their results originate solely from the differences in aerosol modeling. 
(a) US: $2030-2005$

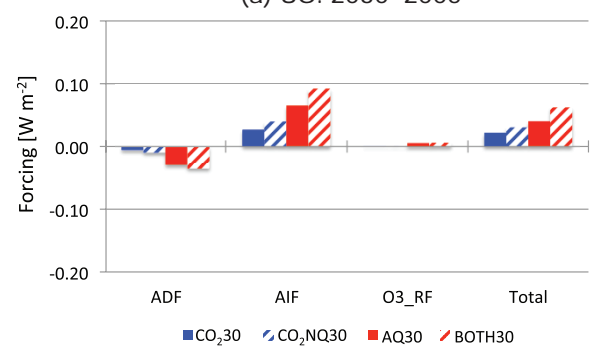

(b) US: 2050-2005

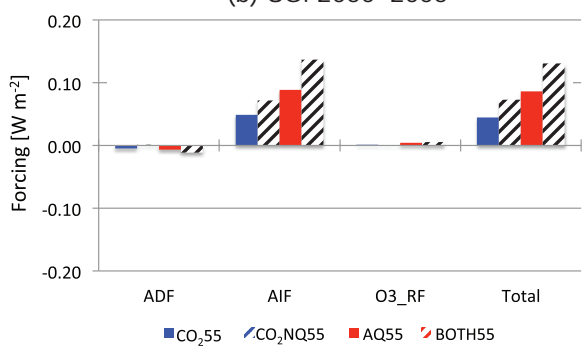

Figure 13. Impact of future warm climate conditions on US averaged radiative forcings in (a) 2030 and (b) 2055 relative to 2005 . Note that $\mathrm{BC}$ albedo forcing is added into aerosol direct forcing (ADF).

(a) US: $2030-2005$

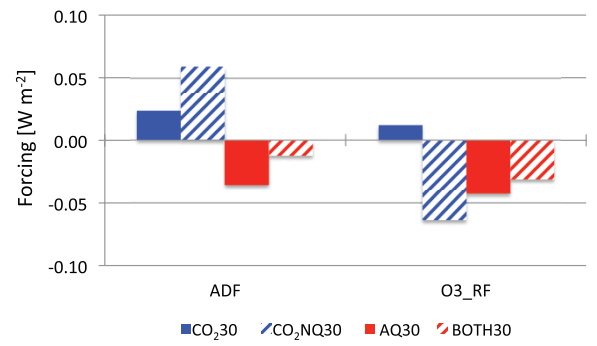

(b) US: 2055-2005

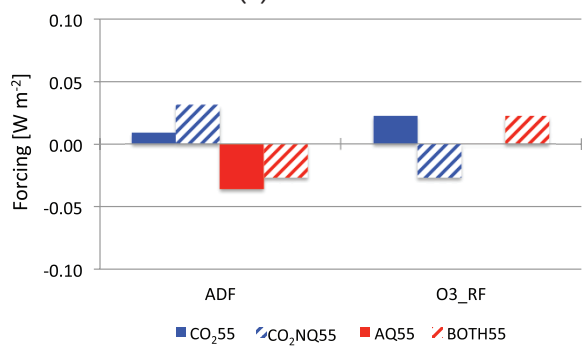

Figure 14. Impact of climate response due to emissions on US averaged radiative forcings in (a) 2030 and (b) 2055 relative to 2005 . Note that $\mathrm{BC}$ albedo forcing is added into aerosol direct forcing (ADF).

We have found that the US air quality regulations are projected to have a strong beneficial impact on US air quality and public health in the future but result in a positive local radiative forcing. For US air quality, we find significant reduction across the pollutant species: on average, $\sim 2 \mu \mathrm{g} \mathrm{m}^{-3}$ reduction for surface $\mathrm{PM}_{2.5}$, and $\sim 8$ ppbv reduction for surface $\mathrm{O}_{3}$. We observe a slight reduction of surface $\mathrm{PM}_{2.5}$ in Eurasia $\left(0.01-0.1 \mu \mathrm{g} \mathrm{m}^{-3}\right)$ and more than $1 \mathrm{ppbv}$ reduction in surface $\mathrm{O}_{3}$ throughout the $\mathrm{NH}$. Based on the $\mathrm{CRF}_{\text {base }}$ (most appropriate CRF for USA), the improved air quality prevents about 91400 premature deaths in the USA, which is combined from $\sim 74200$ and $\sim 17200$ deaths as a result of the $\mathrm{PM}_{2.5}$ and $\mathrm{O}_{3}$ reductions, respectively. However, the estimate is significantly affected by the choice of the CRFs (e.g., a factor of 2 less with the $\mathrm{CRF}_{\text {low }}$ case and a factor of 4-5 higher using the $\mathrm{CRF}_{\text {high }}$ case), indicating that the mortality estimate is very sensitive to the uncertainties in the concentration-response functions. The air quality regulations have strong climate disbenefits over the USA, resulting in an overall $\mathrm{RF}$ of $\sim 0.8 \mathrm{~W} \mathrm{~m}^{-2}$, which is strongly positive due to reflective aerosols.

We have discovered that the $\mathrm{CO}_{2}$ reduction policy has some benefit to air quality via reducing $\mathrm{SO}_{2}$ emissions. Under this policy, the USA relies less on coal, which reduces $\mathrm{SO}_{2}$ emissions significantly. Surface $\mathrm{PM}_{2.5}$ is reduced by $0.4 \mu \mathrm{g} \mathrm{m}^{-3}$ on average over the continental USA in year 2055, which is about $20 \%$ of the impact of air quality regulations ( 0.4 vs. $2 \mu \mathrm{g} \mathrm{m}^{-3}$ ). According to our esti- mates with $\mathrm{CRF}_{\text {base }}$, it prevents $\sim 19200$ premature deaths ( $\sim 19600$ deaths for $\mathrm{PM}_{2.5}$ decrease and $\sim-400$ deaths for $\mathrm{O}_{3}$ increase); ozone is slightly increased in 2055 but it is almost negligible. This indicates that a potentially substantial benefit associated with air quality improvement takes place under the $\mathrm{CO}_{2}$ reduction policy. Our findings agree well with other studies showing air quality co-benefits of a climate policy (e.g., Groosman et al., 2011; Nemet et al., 2010; Thompson et al., 2014). These studies estimate a substantial cost benefit when the health benefits resulted from a $\mathrm{CO}_{2}$ policy is monetized. For instance, Thompson et al. (2014) find that the monetized health co-benefits can be greater than the climate policy implementation costs.

In our study, the $\mathrm{CO}_{2}$ reduction policy results in a net cooling on a global scale due to the loss of cooling aerosols, but the policy leads to a net positive forcing over the USA on a regional scale. Under the $\mathrm{CO}_{2}$ reduction policy, future US energy resources come less from coal (thus, reducing $\mathrm{SO}_{2}$ emissions), which is the main reason for reducing the health impacts from air pollution, but, at the same time, could lead to climate disbenefits over the USA potentially. In the year 2055 (when US $\mathrm{CO}_{2}$ emissions reach half of their 2005 emissions), the US mean total RF is $+0.22 \mathrm{~W} \mathrm{~m}^{-2}$ due to aerosol RF, while the global mean total $\mathrm{RF}$ is $-0.06 \mathrm{~W} \mathrm{~m}^{-2}$ due to the dominant negative $\mathrm{CO}_{2} \mathrm{RF}$ (instantaneous RF). Using the equilibrium $\mathrm{CO}_{2} \mathrm{RF}$ (i.e., year 2150), the $\mathrm{CO}_{2} \mathrm{RF}$ increases from -0.07 to $-0.17 \mathrm{~W} \mathrm{~m}^{-2}$, but it is still not large 
enough to cancel the positive forcing from aerosols in US regions.

Utilizing two independent aerosol models in the same host GCM, we have found that overall conclusions agree well between the two aerosol models, but missing species such as nitrate can influence the air quality and climate impact moderately. Our climate estimates reinforce that aerosol RF is a dominant forcing agent for regional climate change, and AIF is as important as ADF. A climate impact only based on aerosol direct forcing can be misleading, and we strongly suggest including AIF for a more complete assessment of the climate impact of emission scenarios. Since our study utilized a single host GCM, and we recognize that there are large model-to-model differences among GCMs (e.g., Shindell et al., 2013b), we encourage other modeling groups to perform similar work using other host GCMs, to obtain more robust results.

Due to their long lifetime of $\mathrm{CO}_{2}$ (or other long-lived GHGs), the climate benefit from a local $\mathrm{CO}_{2}$ emission reduction is spread spatially (over large areas) and temporally (occurs slowly). This is why it is difficult to achieve regionalscale short-term climate benefits with the $\mathrm{CO}_{2}$ reduction policy alone. It is important to mention that air quality and health co-benefits from the climate policies could be potentially substantial, and these benefits are immediate and hence within a time frame relevant for policymakers.

There are a few options that could help to achieve regionalscale climate benefits under a climate policy. First, as discussed by Akhtar et al. (2013), setting the $50 \% \mathrm{CO}_{2}$ cap in an earlier year than 2030 can help to reduce regional warming by bringing the cooling effects of reductions in $\mathrm{CO}_{2}$ emissions sooner (so that the climate system would have less time to respond to the near-term warming from aerosol reductions). Second, our hypothetical $\mathrm{CO}_{2}$ reduction policy does not target $\mathrm{CH}_{4}$ emissions reductions, but if there is $\mathrm{CH}_{4}$ mitigation, it would lead to a considerable climate benefit both globally and regionally. Rogelj et al. (2015) shows a potentially large climate benefit by very stringent $\mathrm{CH}_{4}$ mitigation, although these might be extremely ambitious. Lastly, all nations taking action to reduce long-lived GHG emissions is the clearest way to achieve regional-scale climate benefits. Along with $\mathrm{CO}_{2}$ reductions, a more comprehensive climate policy with additional reduction targets for light-absorbing aerosols and gases (SLCPs; e.g., $\mathrm{BC}, \mathrm{CH}_{4}$, and $\mathrm{O}_{3}$ ) would help to achieve additional regional climate benefits while increasing the co-benefits to air quality and public health.

\section{Data availability}

The data used in this study are from global-scale climate model simulations using the NASA GISS ModelE2 model. Model output is in the range of tens of gigabytes, and one must be familiar with NASA GISS ModelE2 and TOMAS aerosol microphysics models and their outputs in order to interpret the data correctly. Therefore, we will provide our data upon request. Population data used in our study is the mortality and burden of disease estimates for WHO member states in 2008, which was compiled by World Health Organization (WHO)'s Department of Measurement and Health Information Systems and is available to download from the following website: http://www.who.int/healthinfo/global_burden_ disease/estimates_country_2004_2008.

\section{The Supplement related to this article is available online at doi:10.5194/acp-16-5323-2016-supplement.}

Acknowledgements. The authors thank Dan Loughlin for assistance with interpreting emission scenarios developed using MARKAL. Also, the authors acknowledge Farhan Akhtar in the Department of State for his contribution to the GLIMPSE project, preparing the GLIMPSE emissions files for ModelE2, and providing useful comments for this manuscript.

Edited by: I. Riipinen

\section{References}

Adams, P. J. and Seinfeld, J. H.: Predicting global aerosol size distributions in general circulation models, J. Geophys. Res.-Atmos., 107, 4370, doi:10.1029/2001JD001010, 2002.

Akhtar, F. H., Pinder, R. W., Loughlin, D. H., and Henze, D. K.: GLIMPSE: A Rapid Decision Framework for Energy and Environmental Policy, Environ. Sci. Technol., 47, 12011-12019, doi:10.1021/es402283j, 2013.

Anenberg, S. C., Schwartz, J., Shindell, D., Amann, M., Faluvegi, G., Klimont, Z., Janssens-Maenhout, G., Pozzoli, L., Van Dingenen, R., Vignati, E., Emberson, L., Muller, N. Z., West, J. J., Williams, M., Demkine, V., Hicks, W. K., Kuylenstierna, J., Raes, F., and Ramanathan, V.: Global Air Quality and Health Co-benefits of Mitigating Near-Term Climate Change through Methane and Black Carbon Emission Controls, Environ. Health Perspect., 120, 831-839, doi:10.1289/ehp.1104301, 2012.

Bauer, S. E. and Koch, D.: Impact of heterogeneous sulfate formation at mineral dust surfaces on aerosol loads and radiative forcing in the Goddard Institute for Space Studies general circulation model, J. Geophys. Res.-Atmos., 110, D17202, doi:10.1029/2005jd005870, 2005.

Bell, M. L., Dominici, F., and Samet, J. M.: A Meta-Analysis of Time-Series Studies of Ozone and Mortality With Comparison to the National Morbidity, Mortality, and Air Pollution Study, Epidemiol. Camb. Mass, 16, 436-445, 2005.

Bell, N., Koch, D., and Shindell, D. T.: Impacts of chemistry-aerosol coupling on tropospheric ozone and sulfate simulations in a general circulation model, J. Geophys. Res.-Atmos., 110, D14305, doi:10.1029/2004JD005538, 2005.

Center for International Earth Science Information Network CIESIN - Columbia University and Centro Internacional de Agricultura Tropical - CIAT: Gridded Population of the World, Version 3 (GPWv3): Population Density Grid, Future Estimates, doi:10.7927/H4ST7MRB, 2005. 
Cohen, A., Anderson, H. R., Ostro, B., Pandey, K. D., Krzyzanowski, M., Künzli, N., Gutschmidt, K., Pope III, C. A., Romieu, I., Samset, J. M., and Smith, K. R.: Urban air pollution, in: Comparative Quantification of Health Risks: Global and Regional Burden of Disease due to Selected Major Risk Factors, edited by: Ezzati, M., Lopez, A. D., Rodgers, A., and Murray, C. J. L., 1353-1434, World Health Organization, available at: http://www.who.int/publications/cra/chapters/volume2/ 1353-1434.pdf (last access: 9 September 2015), 2004.

Collins, W. J., Fry, M. M., Yu, H., Fuglestvedt, J. S., Shindell, D. T., and West, J. J.: Global and regional temperature-change potentials for near-term climate forcers, Atmos. Chem. Phys., 13, 2471-2485, doi:10.5194/acp-13-2471-2013, 2013.

Del Genio, A. D. and Yao, M.-S.: Efficient Cumulus Parameterization for Long-Term Climate Studies: The GISS Scheme, in: The Representation of Cumulus Convection in Numerical Models, edited by: Emanuel, K. A. and Raymond, D. J., 181-184, American Meteorological Society, available at: http://link.springer. com/chapter/10.1007/978-1-935704-13-3_18 (last access: 7 August 2015), 1993

Del Genio, A. D., Yao, M.-S., Kovari, W., and Lo, K. K.W.: A Prognostic Cloud Water Parameterization for Global Climate Models, J. Climate, 9, 270-304, doi:10.1175/15200442(1996)009<0270:APCWPF>2.0.CO;2, 1996.

Doherty, R. M., Wild, O., Shindell, D. T., Zeng, G., MacKenzie, I. A., Collins, W. J., Fiore, A. M., Stevenson, D. S., Dentener, F. J., Schultz, M. G., Hess, P., Derwent, R. G., and Keating, T. J.: Impacts of climate change on surface ozone and intercontinental ozone pollution: A multi-model study, J. Geophys. Res.-Atmos., 118, 3744-3763, doi:10.1002/jgrd.50266, 2013.

Fishbone, L. G. and Abilock, H.: Markal, a linear-programming model for energy systems analysis: Technical description of the bnl version, Int. J. Energy Res., 5, 353-375, doi:10.1002/er.4440050406, 1981.

Forster, P., Ramaswamy, V., Artaxo, P., Berntsen, T., Betts, R., Fahey, D. W., Haywood, J., Lean, J., Lowe, D. C., Myhre, G., Nganga, J., Prinn, R., Raga, G., Schulz, M., and Van Dorland, R.: Changes in Atmospheric Constituents and in Radiative Forcing. Chapter 2, available at: http://inis.iaea.org/Search/search.aspx? orig_q=RN:39002468 (last access: 7 August 2015), 2007.

Groosman, B., Muller, N. Z., and O'Neill-Toy, E.: The Ancillary Benefits from Climate Policy in the United States, Environ. Resour. Econ., 50, 585-603, doi:10.1007/s10640-011-94839, 2011.

Hansen, J., Russell, G., Rind, D., Stone, P., Lacis, A., Lebedeff, S., Ruedy, R., and Travis, L.: Efficient 3-Dimensional GlobalModels for Climate Studies - Model-I and Model-II, Mon. Weather Rev., 111, 609-662, 1983.

Henze, D. K., Shindell, D. T., Akhtar, F., Spurr, R. J. D., Pinder, R. W., Loughlin, D., Kopacz, M., Singh, K., and Shim, C.: Spatially Refined Aerosol Direct Radiative Forcing Efficiencies, Environ. Sci. Technol., 46, 9511-9518, doi:10.1021/es301993s, 2012.

Jerrett, M., Burnett, R. T., Pope, C. A., Ito, K., Thurston, G., Krewski, D., Shi, Y., Calle, E., and Thun, M.: Long-Term Ozone Exposure and Mortality, N. Engl. J. Med., 360, 1085-1095, doi:10.1056/NEJMoa0803894, 2009.

Joos, F., Roth, R., Fuglestvedt, J. S., Peters, G. P., Enting, I. G., von Bloh, W., Brovkin, V., Burke, E. J., Eby, M., Edwards, N. R., Friedrich, T., Frölicher, T. L., Halloran, P. R., Holden, P.
B., Jones, C., Kleinen, T., Mackenzie, F. T., Matsumoto, K., Meinshausen, M., Plattner, G.-K., Reisinger, A., Segschneider, J., Shaffer, G., Steinacher, M., Strassmann, K., Tanaka, K., Timmermann, A., and Weaver, A. J.: Carbon dioxide and climate impulse response functions for the computation of greenhouse gas metrics: a multi-model analysis, Atmos. Chem. Phys., 13, 2793 2825, doi:10.5194/acp-13-2793-2013, 2013.

Koch, D., Schmidt, G. A., and Field, C. V.: Sulfur, sea salt, and radionuclide aerosols in GISS ModelE, J. Geophys. Res.-Atmos., 111, D06206, doi:10.1029/2004jd005550, 2006.

Krewski, D., Jerrett, M., Burnett, R. T., Ma, R., Hughes, E., Shi, Y., Turner, M. C., Pope III, C. A., Thurston, G., Calle, E. E., Thun, M. J., Beckerman, B., DeLuca, P., Finkelstein, N., Ito, K., Moore, D. K., Newbold, K. B., Ramsay, T., Ross, Z., Shin, H., and Tempalski, B.: Extended follow-up and spatial analysis of the American Cancer Society study linking particulate air pollution and mortality, Res. Rep. Health Eff. Inst., 140, 5-36, 2009.

Laden, F., Schwartz, J., Speizer, F. E., and Dockery, D. W.: Reduction in fine particulate air pollution and mortality: Extended follow-up of the Harvard Six Cities study, Am. J. Resp. Crit. Care, 173, 667-672, doi:10.1164/rccm.200503-443OC, 2006.

Lamarque, J.-F., Dentener, F., McConnell, J., Ro, C.-U., Shaw, M., Vet, R., Bergmann, D., Cameron-Smith, P., Dalsoren, S., Doherty, R., Faluvegi, G., Ghan, S. J., Josse, B., Lee, Y. H., MacKenzie, I. A., Plummer, D., Shindell, D. T., Skeie, R. B., Stevenson, D. S., Strode, S., Zeng, G., Curran, M., Dahl-Jensen, D., Das, S., Fritzsche, D., and Nolan, M.: Multi-model mean nitrogen and sulfur deposition from the Atmospheric Chemistry and Climate Model Intercomparison Project (ACCMIP): evaluation of historical and projected future changes, Atmos. Chem Phys., 13, 7997-8018, doi:10.5194/acp-13-7997-2013, 2013.

Lee, Y. H. and Adams, P. J.: A Fast and Efficient Version of the TwO-Moment Aerosol Sectional (TOMAS) Global Aerosol Microphysics Model, Aerosol Sci. Technol., 46, 678-689, doi:10.1080/02786826.2011.643259, 2012.

Lee, Y. H., Lamarque, J.-F., Flanner, M. G., Jiao, C., Shindell, D. T., Berntsen, T., Bisiaux, M. M., Cao, J., Collins, W. J., Curran, M., Edwards, R., Faluvegi, G., Ghan, S., Horowitz, L. W., McConnell, J. R., Ming, J., Myhre, G., Nagashima, T., Naik, V., Rumbold, S. T., Skeie, R. B., Sudo, K., Takemura, T., Thevenon, F., Xu, B., and Yoon, J.-H.: Evaluation of preindustrial to presentday black carbon and its albedo forcing from Atmospheric Chemistry and Climate Model Intercomparison Project (ACCMIP), Atmos. Chem. Phys., 13, 2607-2634, doi:10.5194/acp13-2607-2013, 2013.

Lee, Y. H., Adams, P. J., and Shindell, D. T.: Evaluation of the global aerosol microphysical ModelE2-TOMAS model against satellite and ground-based observations, Geosci. Model Dev., 8, 631-667, doi:10.5194/gmd-8-631-2015, 2015.

Leibensperger, E. M., Mickley, L. J., Jacob, D. J., Chen, W.-T., Seinfeld, J. H., Nenes, A., Adams, P. J., Streets, D. G., Kumar, N., and Rind, D.: Climatic effects of 1950-2050 changes in US anthropogenic aerosols - Part 2: Climate response, Atmos. Chem. Phys., 12, 3349-3362, doi:10.5194/acp-12-3349-2012, 2012.

Loughlin, D. H., Benjey, W. G., and Nolte, C. G.: ESP v1.0: methodology for exploring emission impacts of future scenarios in the United States, Geosci. Model Dev., 4, 287-297, doi:10.5194/gmd-4-287-2011, 2011. 
Mann, G. W., Carslaw, K. S., Reddington, C. L., Pringle, K. J., Schulz, M., Asmi, A., Spracklen, D. V., Ridley, D. A., Woodhouse, M. T., Lee, L. A., Zhang, K., Ghan, S. J., Easter, R. C., Liu, X., Stier, P., Lee, Y. H., Adams, P. J., Tost, H., Lelieveld, J., Bauer, S. E., Tsigaridis, K., van Noije, T. P. C., Strunk, A., Vignati, E., Bellouin, N., Dalvi, M., Johnson, C. E., Bergman, T., Kokkola, H., von Salzen, K., Yu, F., Luo, G., Petzold, A., Heintzenberg, J., Clarke, A., Ogren, J. A., Gras, J., Baltensperger, U., Kaminski, U., Jennings, S. G., O’Dowd, C. D., Harrison, R. M., Beddows, D. C. S., Kulmala, M., Viisanen, Y., Ulevicius, V., Mihalopoulos, N., Zdimal, V., Fiebig, M., Hansson, H.-C., Swietlicki, E., and Henzing, J. S.: Intercomparison and evaluation of global aerosol microphysical properties among AeroCom models of a range of complexity, Atmos. Chem. Phys., 14, 4679-4713, doi:10.5194/acp-14-4679-2014, 2014.

Marlier, M. E., DeFries, R. S., Voulgarakis, A., Kinney, P. L., Randerson, J. T., Shindell, D. T., Chen, Y., and Faluvegi, G.: El Nino and health risks from landscape fire emissions in southeast Asia, Nat. Clim. Change, 3, 131-136, doi:10.1038/nclimate1658, 2013

Menon, S., Del Genio, A. D., Koch, D., and Tselioudis, G.: GCM Simulations of the aerosol indirect effect: Sensitivity to cloud parameterization and aerosol burden, J. Atmos. Sci., 59, 692-713, doi:10.1175/1520-0469(2002)059<0692: gsotai>2.0.co;2, 2002.

Menon, S., Del Genio, A. D., Kaufman, Y., Bennartz, R., Koch, D., Loeb, N., and Orlikowski, D.: Analyzing signatures of aerosolcloud interactions from satellite retrievals and the GISS GCM to constrain the aerosol indirect effect, J. Geophys. Res.-Atmos., 113, D14S22, doi:10.1029/2007jd009442, 2008.

Mishchenko, M. I., Travis, L. D., and Mackowski, D. W.: T-matrix computations of light scattering by nonspherical particles: A review, J. Quant. Spectrosc. Ra., 55, 535-575, doi:10.1016/00224073(96)00002-7, 1996.

Naik, V., Voulgarakis, A., Fiore, A. M., Horowitz, L. W., Lamarque, J.-F., Lin, M., Prather, M. J., Young, P. J., Bergmann, D., Cameron-Smith, P. J., Cionni, I., Collins, W. J., Dalsøren, S. B., Doherty, R., Eyring, V., Faluvegi, G., Folberth, G. A., Josse, B., Lee, Y. H., MacKenzie, I. A., Nagashima, T., van Noije, T. P. C., Plummer, D. A., Righi, M., Rumbold, S. T., Skeie, R., Shindell, D. T., Stevenson, D. S., Strode, S., Sudo, K., Szopa, S., and Zeng, G.: Preindustrial to present-day changes in tropospheric hydroxyl radical and methane lifetime from the Atmospheric Chemistry and Climate Model Intercomparison Project (ACCMIP), Atmos. Chem. Phys., 13, 5277-5298, doi:10.5194/acp-13-5277-2013, 2013.

Nemet, G. F., Holloway, T., and Meier, P.: Implications of incorporating air-quality co-benefits into climate change policymaking, Environ. Res. Lett., 5, 014007, doi:10.1088/17489326/5/1/014007, 2010.

Nenes, A. and Seinfeld, J. H.: Parameterization of cloud droplet formation in global climate models, J. Geophys. Res.-Atmos., 1984-2012, 108, doi:10.1029/2002JD002911, 2003.

Olivié, D. J. L. and Peters, G. P.: Variation in emission metrics due to variation in $\mathrm{CO}_{2}$ and temperature impulse response functions, Earth Syst. Dynam., 4, 267-286, doi:10.5194/esd-4-267-2013, 2013.

Pierce, J. R., Chen, K., and Adams, P. J.: Contribution of primary carbonaceous aerosol to cloud condensation nuclei: processes and uncertainties evaluated with a global aerosol microphysics model, Atmos. Chem. Phys., 7, 5447-5466, doi:10.5194/acp-75447-2007, 2007.

Pope, C. A., Burnett, R. T., Thun, M. J., Calle, E. E., Krewski, D., Ito, K., and Thurston, G. D.: Lung cancer, cardiopulmonary mortality, and long-term exposure to fine particulate air pollution, JAMA, 287, 1132-1141, 2002.

Pope, C. A., Burnett, R. T., Turner, M. C., Cohen, A., Krewski, D., Jerrett, M., Gapstur, S. M., and Thun, M. J.: Lung cancer and cardiovascular disease mortality associated with ambient air pollution and cigarette smoke: shape of the exposureresponse relationships, Environ. Health Persp., 119, 1616-1621, doi:10.1289/ehp.1103639, 2011.

Prather, M. J.: Numerical Advection by Conservation of 2nd-Order Moments, J. Geophys. Res.-Atmos., 91, 6671-6681, 1986.

Rogelj, J., Meinshausen, M., Schaeffer, M., Knutti, R., and Riahi, $\mathrm{K}$.: Impact of short-lived non- $\mathrm{CO}_{2}$ mitigation on carbon budgets for stabilizing global warming, Environ. Res. Lett., 10, 075001, doi:10.1088/1748-9326/10/7/075001, 2015.

Roman, H. A., Walker, K. D., Walsh, T. L., Conner, L., Richmond, H. M., Hubbell, B. J., and Kinney, P. L.: Expert Judgment Assessment of the Mortality Impact of Changes in Ambient Fine Particulate Matter in the US, Environ. Sci. Technol., 42, 22682274, doi:10.1021/es0713882, 2008.

Schmidt, G. A., Ruedy, R., Hansen, J. E., Aleinov, I., Bell, N., Bauer, M., Bauer, S., Cairns, B., Canuto, V., Cheng, Y., Del Genio, A., Faluvegi, G., Friend, A. D., Hall, T. M., Hu, Y., Kelley, M., Kiang, N. Y., Koch, D., Lacis, A. A., Lerner, J., Lo, K. K., Miller, R. L., Nazarenko, L., Oinas, V., Perlwitz, J., Perlwitz, J., Rind, D., Romanou, A., Russell, G. L., Sato, M., Shindell, D. T., Stone, P. H., Sun, S., Tausnev, N., Thresher, D., and Yao, M.S.: Present-Day Atmospheric Simulations Using GISS ModelE: Comparison to In Situ, Satellite, and Reanalysis Data, J. Climate, 19, 153-192, doi:10.1175/JCLI3612.1, 2006.

Schmidt, G. A., Kelley, M., Nazarenko, L., Ruedy, R., Russell, G. L., Aleinov, I., Bauer, M., Bauer, S. E., Bhat, M. K., Bleck, R., Canuto, V., Chen, Y.-H., Cheng, Y., Clune, T. L., Del Genio, A., de Fainchtein, R., Faluvegi, G., Hansen, J. E., Healy, R. J., Kiang, N. Y., Koch, D., Lacis, A. A., LeGrande, A. N., Lerner, J., Lo, K. K., Matthews, E. E., Menon, S., Miller, R. L., Oinas, V., Oloso, A. O., Perlwitz, J. P., Puma, M. J., Putman, W. M., Rind, D., Romanou, A., Sato, M., Shindell, D. T., Sun, S., Syed, R. A., Tausnev, N., Tsigaridis, K., Unger, N., Voulgarakis, A., Yao, M.-S., and Zhang, J.: Configuration and assessment of the GISS ModelE2 contributions to the CMIP5 archive, J. Adv. Model. Earth Syst., 6, 141-184, doi:10.1002/2013ms000265, 2014.

Schnell, J. L., Prather, M. J., Josse, B., Naik, V., Horowitz, L. W., Cameron-Smith, P., Bergmann, D., Zeng, G., Plummer, D. A., Sudo, K., Nagashima, T., Shindell, D. T., Faluvegi, G., and Strode, S. A.: Use of North American and European air quality networks to evaluate global chemistry-climate modeling of surface ozone, Atmos. Chem. Phys., 15, 10581-10596, doi:10.5194/acp-15-10581-2015, 2015.

Seinfeld, J. H. and Pandis, S. N.: Atmospheric Chemistry and Physics, John Wiley and Sons, New York, USA, 1998.

Shindell, D. and Faluvegi, G.: Climate response to regional radiative forcing during the twentieth century, Nat. Geosci., 2, 294-300, doi:10.1038/ngeo473, 2009.

Shindell, D., Faluvegi, G., Walsh, M., Anenberg, S. C., Van Dingenen, R., Muller, N. Z., Austin, J., Koch, D., and Milly, 
G.: Climate, health, agricultural and economic impacts of tighter vehicle-emission standards, Nat. Clim. Change, 1, 59-66, doi:10.1038/nclimate1066, 2011.

Shindell, D., Kuylenstierna, J. C. I., Vignati, E., van Dingenen, R., Amann, M., Klimont, Z., Anenberg, S. C., Muller, N., Janssens-Maenhout, G., Raes, F., Schwartz, J., Faluvegi, G., Pozzoli, L., Kupiainen, K., Hoeglund-Isaksson, L., Emberson, L., Streets, D., Ramanathan, V., Hicks, K., Oanh, N. T. K., Milly, G., Williams, M., Demkine, V., and Fowler, D.: Simultaneously Mitigating Near-Term Climate Change and Improving Human Health and Food Security, Science, 335, 183-189, doi:10.1126/science.1210026, 2012.

Shindell, D. T., Faluvegi, G., Unger, N., Aguilar, E., Schmidt, G. A., Koch, D. M., Bauer, S. E., and Miller, R. L.: Simulations of preindustrial, present-day, and 2100 conditions in the NASA GISS composition and climate model G-PUCCINI, Atmos. Chem. Phys., 6, 4427-4459, doi:10.5194/acp-6-4427-2006, 2006.

Shindell, D. T., Pechony, O., Voulgarakis, A., Faluvegi, G., Nazarenko, L., Lamarque, J.-F., Bowman, K., Milly, G., Kovari, B., Ruedy, R., and Schmidt, G. A.: Interactive ozone and methane chemistry in GISS-E2 historical and future climate simulations, Atmos. Chem. Phys., 13, 2653-2689, doi:10.5194/acp-13-26532013, 2013a.

Shindell, D. T., Lamarque, J.-F., Schulz, M., Flanner, M., Jiao, C., Chin, M., Young, P. J., Lee, Y. H., Rotstayn, L., Mahowald, N., Milly, G., Faluvegi, G., Balkanski, Y., Collins, W. J., Conley, A. J., Dalsoren, S., Easter, R., Ghan, S., Horowitz, L., Liu, X., Myhre, G., Nagashima, T., Naik, V., Rumbold, S. T., Skeie, R., Sudo, K., Szopa, S., Takemura, T., Voulgarakis, A., Yoon, J.-H., and Lo, F.: Radiative forcing in the ACCMIP historical and future climate simulations, Atmos. Chem. Phys., 13, 2939-2974, doi:10.5194/acp-13-2939-2013, 2013 b.
Shindell, D. T., Lee, Y., and Faluvegi, G.: Climate and health impacts of US emissions reductions consistent with $2{ }^{\circ} \mathrm{C}$, Nat. Clim. Change, advance online publication, doi:10.1038/nclimate2935, 2016.

Thompson, T. M., Rausch, S., Saari, R. K., and Selin, N. E.: A systems approach to evaluating the air quality cobenefits of US carbon policies, Nat. Clim. Change, 4, 917-923, doi:10.1038/nclimate2342, 2014.

Thomson, A. M., Calvin, K. V., Smith, S. J., Kyle, G. P., Volke, A., Patel, P., Delgado-Arias, S., Bond-Lamberty, B., Wise, M. A., Clarke, L. E., and Edmonds, J. A.: RCP4.5: a pathway for stabilization of radiative forcing by 2100 , Clim. Change, 109 , 77-94, doi:10.1007/s10584-011-0151-4, 2011.

United Nations, Department of Economic and Social Affairs, Population Division: World Population Prospects: The 2010 Revision, Volume 1: Comprehensive Tables, New York, USA, 2011.

US Environmental Protection Agency: Endangerment and cause or contribute findings for greenhouse gases under section 202(a) of the clean air act, available at: http://www.epa.gov/climatechange/ Downloads/endangerment/Endangerment_TSD.pdf (last access: 6 November 2015), 2009.

US Environmental Protection Agency: Air, Climate, and Energy, available at: http://www2.epa.gov/sites/production/files/ 2014-06/documents/strap-ace2012.pdf (last access: 6 November 2015), 2012.

Vehkamaki, H., Kulmala, M., Napari, I., Lehtinen, K. E. J., Timmreck, C., Noppel, M., and Laaksonen, A.: An improved parameterization for sulfuric acid-water nucleation rates for tropospheric and stratospheric conditions, J. Geophys. Res.-Atmos., 107, 4622, doi:10.1029/2002JD002184, 2002. 